\title{
Poly-(ADP-ribose)-polymerase inhibitors as radiosensitizers: a systematic review of pre-clinical and clinical human studies
}

\author{
Paul Lesueur ${ }^{1,2}$, François Chevalier ${ }^{1}$, Jean-Baptiste Austry ${ }^{1}$, Waisse Waissi ${ }^{3}$, Hélène \\ Burckel $^{3}$, Georges Noël ${ }^{3}$, Jean-Louis Habrand ${ }^{2}$, Yannick Saintigny ${ }^{1, *}$ and Florence \\ Joly ${ }^{4, *}$ \\ ${ }^{1}$ Laboratoire d'Accueil et de Recherche avec les Ions Accélérés, CEA, CIMAP-GANIL, 14000 Caen, France \\ ${ }^{2}$ Centre Francois Baclesse Centre de Lutte Contre le Cancer, Radiotherapy Unit, 14000 Caen, France \\ ${ }^{3}$ EA 3430, Laboratoire de Radiobiologie, Centre Paul Strauss, 67000 Strasbourg, France \\ ${ }^{4}$ Centre Francois Baclesse Centre de Lutte Contre le Cancer, Clinical Research Unit, 14000 Caen, France \\ *These authors contributed equally to this work and are co last authors \\ Correspondence to: Paul Lesueur, email: Paul.Lesueur89@gmail.com
}

Keywords: radiosensitization, poly(ADP-ribose)-polymerase inhibitors, radiotherapy, radiobiology

Received: May 27, $2017 \quad$ Accepted: June 19, $2017 \quad$ Published: July 07, 2017

Copyright: Lesueur et al. This is an open-access article distributed under the terms of the Creative Commons Attribution License 3.0 (CC BY 3.0), which permits unrestricted use, distribution, and reproduction in any medium, provided the original author and source are credited.

\section{ABSTRACT}

Background: Poly-(ADP-Ribose)-Polymerase (PARP) inhibitors are becoming important actors of anti-neoplasic agents landscape, with recent but narrow FDA's approvals for ovarian BRCA mutated cancers and prostatic cancer. Nevertheless, PARP inhibitors are also promising drugs for combined treatments particularly with radiotherapy. More than seven PARP inhibitors have been currently developed. Central Role of PARP in DNA repair, makes consider PARP inhibitor as potential radiosensitizers, especially for tumors with DNA repair defects, such as BRCA mutation, because of synthetic lethality. Furthermore the replication-dependent activity of PARP inhibitor helps to maintain the differential effect between tumoral and healthy tissues. Inhibition of chromatin remodeling, G2/M arrest, vasodilatory effect induced by PARP inhibitor, also participate to their radio-sensitization effect.

Materials and Methods: Here, after highlighting mechanisms of PARP inhibitors radiosensitization we methodically searched PubMed, Google Scholar, Cochrane Databases and meeting proceedings for human pre-clinical and clinical studies that evaluated PARP inhibitor radiosensitizing effect. Enhancement ratio, when available, was systematically reported.

Results: Sixty four studies finally met our selection criteria and were included in the analysis. Only three pre-clinical studies didn't find any radiosensitizing effect. Median enhancement ratio vary from 1,3 for prostate tumors to 1,5 for lung cancers. Nine phase I or II trials assessed safety data.

Conclusion: PARP inhibitors are promising radiosensitizers, but need more clinical investigation. The next ten years will be determining for judging their real potential.

\section{INTRODUCTION}

Poly-(adenosine diphosphate-ribose)-polymerase(PARP) is a family of enzymes involved in a wide number of cellular processes, including DNA replication, transcription, repair and cell death. PARP proteins have been studied for decades for notably their roles in DNA repair. PARP1 is the most abundant and active enzyme of the PARP family, but roles of other members including PARP2 and PARP3 in DNA damage responses is emerging. In fact, they play an important role by detecting the presence of damaged DNA and then by activating signalization pathways that promote appropriate cellular responses. PARP is involved in base excision repair (BER) by allowing the recruitment and activation of BER 
actors and consequently make easier the DNA single strand break (SSB) reparation. Further studies have shown that PARP1 and PARP-2 were also implicated in DNA breaks repair by Non-Homologous End Joining (NHEJ) and Homologous Recombination (HR).

Increased PARP activity has been observed in numerous cancers, and has been sounded to be one possible mechanism of resistance to cell-death by DNAdamaging therapeutics. Then progressively, PARP proteins became a very interesting target for oncologic treatments, and first PARP inhibitors (PARPi) were designed at the end of the eighties. Indeed, 2005 year has been a real turning point for the development of PARPi as two highvalue publications showed that dysfunction of homologous recombination such as in BRCA1 and BRCA2 mutated cells triggered a high sensitization to PARPi [1, 2]. PARPi leads to the persistence of DNA lesions normally repaired by homologous recombination. Then, such accumulation of non-repaired DNA lesions leads to cell death. Synthetic lethality was then confirmed as a serious avenue of therapeutic development. PARP inhibitors have been evaluated in clinical trials either as single agents or in combination with DNA damaging agents. Olaparib, the most developed PARPi, has been approved by the FDA for treatment of Ovarian and Prostate BRCA mutated cancers. Many others molecules are being developed such as rucaparib, talazoparib, niraparib, veliparib, or simmiparib.

Classically, radiosensitivity is described as function of the tumor intrinsic radiosensitivity, the tumor repair capacity, the reoxygenation process, the cell cycle redistribution, and the tumoral tissue repopulation. More recently, with development of stereotactic radiotherapy, two additional characteristics appeared: the tumor immunity and the vascular endothelial damage process [3]. So, a radiosensitizer has to impact one or more of these processes without worsening the treatment toxicity. The combination of ionizing radiation with radio-enhancing agents represents an opportunity to increase the efficacy of radiotherapy as a treatment modality, and at the same time minimize toxic side effects and potential damages to healthy surrounding tissues. PARPi have many qualities required for radio sensitizing effects (Figure 1) and since the last ten years, they have become interesting molecules as radiosensitizers. There is evidence that the absence of PARP-1 and -2, which are both activated by DNA damage and facilitate DNA repair, produces an hypersensitivity to ionizing radiation. Therefore, the inhibition of PARPmediated DNA damage repair can help to sensitize cells to radiation by prolonging strand breaks and by leading to a cell-death signaling pathway. This effect could be enhanced in cancers harboring defects in homologous recombination and by synthetic lethality mechanism. Nevertheless modulating DNA damage repair is not the only way of the radiosensistizing effect of PARPi.

The scope of this systematic review is to make a state of the art about advancements of PARPi use as radiosensitizer in human tumor cells and to provide food for clinician's thought who would wish to study radiosensitization methods. Each organs group will be treated separately. Before results of the systematic review, principal mechanisms of PARPI radiosensitization will be reminded.

\section{Mechanisms of radiosensitization of PARP inhibitors}

\section{Inhibition of DNA repair}

PARPs are involved in several DNA repair mechanisms such as: Base Excision repair (BER), homologous recombination (HR), conventional (c-NHEJ) or alternative non-homologous end joining repair (altNHEJ) [4-6].

PARP is one of the first actors of DNA single strand break (SSB) repair because of its role in BER. PARP is a part of the BER complex, described as a sensor of SSB. PARP-1 and 2 are the two most important PARP family enzymes implicated in BER. In fact, PARP detects SSB and leads to PARylation, meaning accumulation of polyADP-ribose (PAR) chain around the SSB [7, 8]. The local PARylation allows the recruitment of XRCC1 for break stabilization, DNA Polymerase $\beta$ for the complementary base synthesis, and DNA ligase III for final ligation [9]. Auto-PARylation of PARP releases PARP from the SSB site. In case of PARP inhibition, PARP stays set on SSB site, BER machinery is not recruited, and SSB persists.

Associated with PARPi, radiation therapy would induce DNA damages, such as SSB or DSB which couldn't be repaired, and driving to DNA replication fork collapse. $\mathrm{SSB}$ is then converted in potentially lethal double strand break (DSB). PARPi are also trapped to DNA and induce "mechanical" replication fork collapse and consequently DSB [10]. It explains why PARP inhibition is more effective than PARP suppression [11]. That's the first and main radio sensitizing effect of PARPi. If homologous recombination deficient cells are considered, such as BRCA mutated or BRCAness ones [12], the effect is more potent: it is an example of synthetic lethality mechanism.

$\mathrm{HR}$ is an error free DNA repair mechanism in which PARP1-2 play again a sensor role, by making easier the recruitment of MRE11, DNA resection, and replication restart $[10,13]$. Furthermore PARP-1 regulate $\mathrm{RH}$, and can promote RH instead of error prone NHEJ. PARP inhibition prevents the use of efficient and reliable DNA repair system $[5,13]$.

There has been evidence, that an alternative endjoining (Alt-NHEJ) operates in the absence of the core components of classical NHEJ [14]. Alt-NHEJ is efficient, but highly mutagenic. PARP-1 is even known for his central role in alternative NHEJ [4]. PARPi suppress again this way of repair and lead to more DNA radiation damages. 
As a conclusion the use of PARPi allow to target most of DNA repair system, so as to potentiate the radiotherapy effect by accumulating SSB and above all DSB.

\section{Replication-dependent radiosensitization}

PARPi exercise their radiosensitizing effect, more specifically, during the cell cycle $S$ phase [15]. For example with olaparib, in Dungey's glioblastoma cells study, radiosensitization was significantly more pronounced in S-phase (enhancement ratio at 50\% survival: SER50 $=1.60)$ than in G1 $($ SER50 $=1.27$ ) or G2 $($ SER50 $=1.33)$ enriched populations [16]. Moreover it is well known that tumor have a higher proliferating cell compartment in comparison to surround safe tissues. It means that PARPi may radiosensitize tumor tissue, while saving non tumoral tissue, which is one of the most important qualities of a radiosensitizing agent.

\section{Modulation of chromatin remodeling}

PARP-1 dependent PARylation event directs the recruitment of helicase, such as ALC1 (amplified in liver cancer 1) to chromatin and nucleosomes [17, 18]. The helicase activity promotes the unwinding of DNA double helix and unblocks access to DNA of the machinery responsible for transcription, replication and DNA repair $[17,19]$. After treatments by DNA damage agents just as irradiation, inhibition of PARP-1 could delay DNA double strand opening and DNA repair. It could be considered as another way of PARPi potential radiosensitization.
Impact on microenvironnement and role of hypoxia

PARPi association with radiotherapy could help to bypass the hypoxia induced radioresistance. On the first hand, few PARPi, like rucaparib for example, have structural similarities with nicotinamide, a vaso-dilatory component. This specificity could enhance tumor growth delay after radiotherapy, by increasing tumor blood flow, enhancing drug penetration, and increasing oxygen concentrations to offset hypoxic cell radioresistance [20]. It could explain why sometimes PARP efficiency is higher in vivo than in vitro [20]. PARPi radiosensitize hypoxic tumor thanks to an oxygen effect. Ionizing radiation depends heavily on the presence of molecular oxygen to produce cytotoxic effect. The molecular oxygen $\mathrm{O} 2$ is absolutely necessary to chemically fix DNA free radicals produced by ionizing radiation [21]. In the absence of $\mathrm{O} 2$, DNA radicals are repaired by abstracting hydrogen from sulfhydryl (SH) group present in protein [21]. It has been reported that three times higher ionizing radiation dose is required to kill hypoxic cancer cells, compared to welloxygenated cells, in order to achieve the equivalent level of cell kill [22, 23].

On the other hand, even without any improvement of the vasculature, PARPi exibit a radiosensitizing effect in hypoxic cells. In fact hypoxia generates a genetic instability by a mutator phenotype effect [24] linked to the decreased transcription of proteins involved in homologous recombination [25]. When PARPi and radiotherapy are combined in hypoxic conditions, we

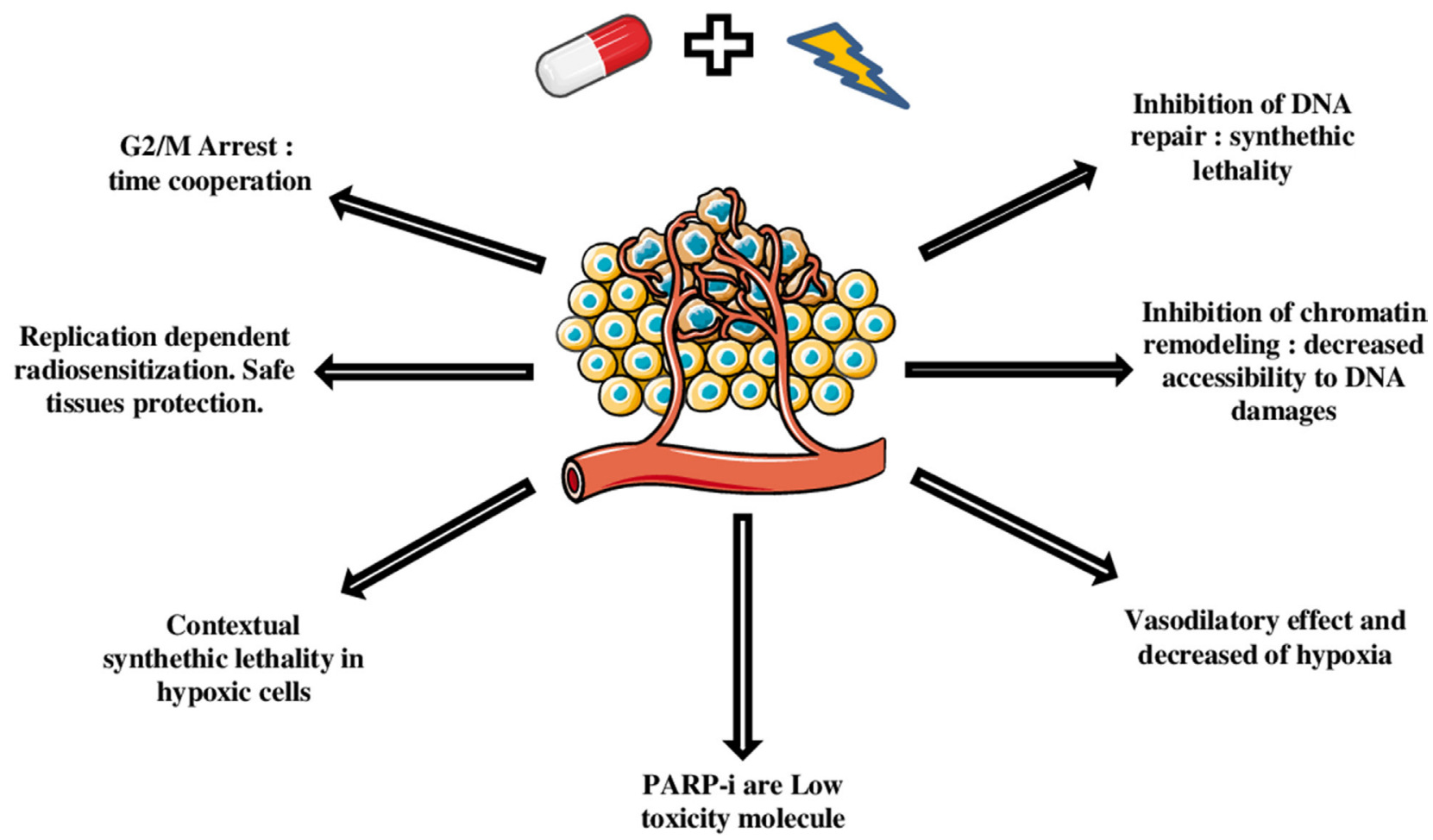

Figure 1: Mechanisms and advantages of PARPi radiosensitization. 
could observe contextual synthetic lethality. HR is altered by hypoxia and carries out an increased death ratio [26].

\section{G2/M arrest}

With DNA repair, cell cycle regulation is perhaps the most important determinant of ionizing radiation sensitivity. A common cellular response to DNA-damaging agents is the activation of cell cycle checkpoints, leading to cell cycle arrest [27]. The concomitant radiochemotherapy induces temporo-spatial cooperation. Spatial cooperation means that chemotherapy allows to cure overfield micro metastatic disease, whereas radiotherapy goal is to treat local invasion. Temporal cooperation means that chemotherapy synchronizes, and arrests cells in the radiosensitive phases of the cell cycle: G2 and M. In this context of temporal cooperation, chemotherapy could be considered as a radiosensitizer. PARPi could take part into the radiosensitization process in the same way as a result of the G2/M arrest induced, secondary to chromosomic aberrations generated by PARPi [1].

\section{Low toxicity molecule}

Most used radiosensitizers, such as Cisplatin or Cetuximab, induce major systemic secondary effects, which could limit their use in clinical practice particularly for elderly patients such as: neuropathy, cytopenia, nephropathy, cutaneous toxicity. In phase II-III clinical trials studying PARPi monotherapy, toxicity remains manageable and consists most of the time of anemia, thrombocytopenia, neutropenia, asthenia and nauseas rarely upper than grade II [23-26].

This low toxicity lets suggest that PARPi use as radiosensitizer shouldn't worsen treatment safety.

\section{PARPi available or being developed}

First PARPi were born at the beginning of the eighties and were derived from 3-aminobenzamide. Due to its lack of potency and specificity, 3-AB is not clinically useful. Therefore, a number of third-generation PARP inhibitors, some derived from the 3-AB structure, have been developed in recent years and tested in pre-clinical and clinical studies. Their development has been faster during the second half of 2000's, corresponding to the discover of anti tumoral response in BRCA mutated cells by Bryant and Farmer [1,2]. PARPi suppress activity of PARP catalytic domain explaining synthetic lethality in HR defective cells. Nevertheless, PARP inhibition, delays SSB repair to a greater extent than PARP depletion [11]. To explain these results, a PARP-1 trapping has been proposed based on the idea that PARP1 is trapped on DNA by PARP inhibitors, and PARP1-DNA complexes can interfere with DNA fork replication $[32,33]$.

Actually seven PARPi are being developped by pharmaceutical industry in clinical trials: Olaparib,
Rucaparib, Niraparib, talazoparib, veliparib, CEP 9722, Simmiparib. They are all oral drugs. Among them only Rucaparib, Olaparib, Niraparib and Veliparib have been used as radiosensitizers. Others PARPi such as LT626, PJ34, GPI 21016, 3-Aminobenzamide or 4-amino-1,8naphthalimide have been less employed, and only in preclinical studies (Table 1).

\section{MATERIALS AND METHODS}

We have led our bibliographic research in accordance with PRISMA guidelines [34]. We looked for all clinical or pre-clinical studies related to the use of PARPi as radiosensistizers. We have requested PubMed, Cochrane and Google Scholar databases without any date limite and thus all the archives of meeting abstracts or posters of ASTRO, ESTRO, ESMO and ASCO congresses from 2010 to 2016. For PubMed Database, the key words research strategy was: "(((radiosensitization) OR radiotherapy)) AND (((c(((niraparib) OR talazoparib) OR rucaparib) OR veliparib) OR olaparib)) OR "Poly(ADPribose) Polymerase Inhibitors" [Mesh])" We have selected all research papers published in English language until June 2017 7th. Studies dealing with animal cells were not included in the systematic review. Then we have excluded reviews, and articles which finally didn't treat about radiotherapy, such as, for example, use of radionuclides. After manuscripts reviewing and application of inclusion criteria, we have sorted the articles function of research stage: in vitro, in vivo or clinical studies. For each selected article we have extracted an enhancement ratio which refers to the enhancement effect of radiation due to the addition of PARPi. Enhancement ratio is classically a ratio between doses associated with surviving fractions of $10 \%$, $37 \%$ or $50 \%$ with or without the PARPi. For example: SER37 = D37(no drug)/D37(PARPi). When enhancement ratio (ER) wasn't communicated as for in vivo studies, clinical studies or few in vitro studies, we have supplied a significant data such as survival, tumor growth delay. Then data are assembled and discussed by organ groups.

\section{RESULTS}

After applying our selection criteria, 60 studies have been included from Pubmed and Google scholar analysis. Four more clinical studies have been added after reviewing European, and American congress meeting abstracts, since 2010. Fifty five of the 64 selected studies are pre-clinical in vitro or in vivo studies. For $49 \%$ of pre-clinical studies, it has been possible to extract an enhancement ratio. For others studies, a significant result about the efficacy of the association has been given. Studies about brain or digestive tumors represent $52 \%$ of studies dealing with PARPi as radiosensitizer. Median enhancement ratio vary from 1,30 for prostate tumors to, 5 for lung cancers. Until June 2017 7th, there was no data with Talazoparib, 
Simmaparib or CEP 9722 use with radiotherapy. It is worth noting that all studies meeting our review selection criterias, are presented in the tables (Figure 2).

\section{PARPi + radiotherapy for brain tumors}

Glioblastoma is probably the tumor which could benefit he most from radiosensitizing drugs. Indeed, glioblastoma is considered as a radioresistant tumor with a high level of intra-field recurrence. Furthermore the target is surrounded of high risk complications healthy tissues. Contrary to glioblastoma cells, neurons don't seem to express PARP-1 [49] and are low replication cells: this aids to protect healthy tissues by radiosensitizing only tumor cells. Glioblastoma stem cells promote radioresistance and could be the source of tumor recurrence after radiation [50]. Results from Venere et al. studies highlight constitutive activation of PARP1 in glioblastoma stem cells that can be therapeutically exploited. They showed that PARPi plus radiation compromises the stem cell phenotype in vivo and inhibits glioblastoma stem cells enrichment [51]. Concurrent Temozolomide (TMZ) + Irradiation followed by adjuvant TMZ is standard-of-care for patients suffering from glioblastoma [52]. In that case PARPi inh could be considered as a radio and chemosensitizing drugs [53, 54]. PARPi lead to glioblastoma cells radiosensitization with most of in vitro/in vivo studies which are promising with radiosensitizing enhancement ratio comprised between 1,05 and 1,93 (Table 2). Thanks to inhibition of BER, PARPi prevent repair of N7-guanine and N3-adenine methylation induced by TMZ, increase DNA strand breaks and is responsible of a TMZ chemosensitization [53, 54] even on glioblastoma stem cell [55]. Data concerning the role of PARPi as TMZ chemosensitizer depending on MGMT status stay debated [40, 56-58]even if some phase IIIII clinical trials recruits only patients with methylated MGMT (NCT0215298). Moreover, PARPi could induce synthetic lethality in PTEN deleted glioblastoma (36\% of Glioblastoma) suggesting that it might be logical to treat PTEN-deficient glioblastomas with PARP inhibitors in the future [59]. In summary, PARPi, in combination with radiation therapy induce a median enhancement ratio of 1,30 .

It is worth noting that the ability for some PARP inhibitors to cross the blood-brain barrier has been validated like Veliparib [60]. Promising results are

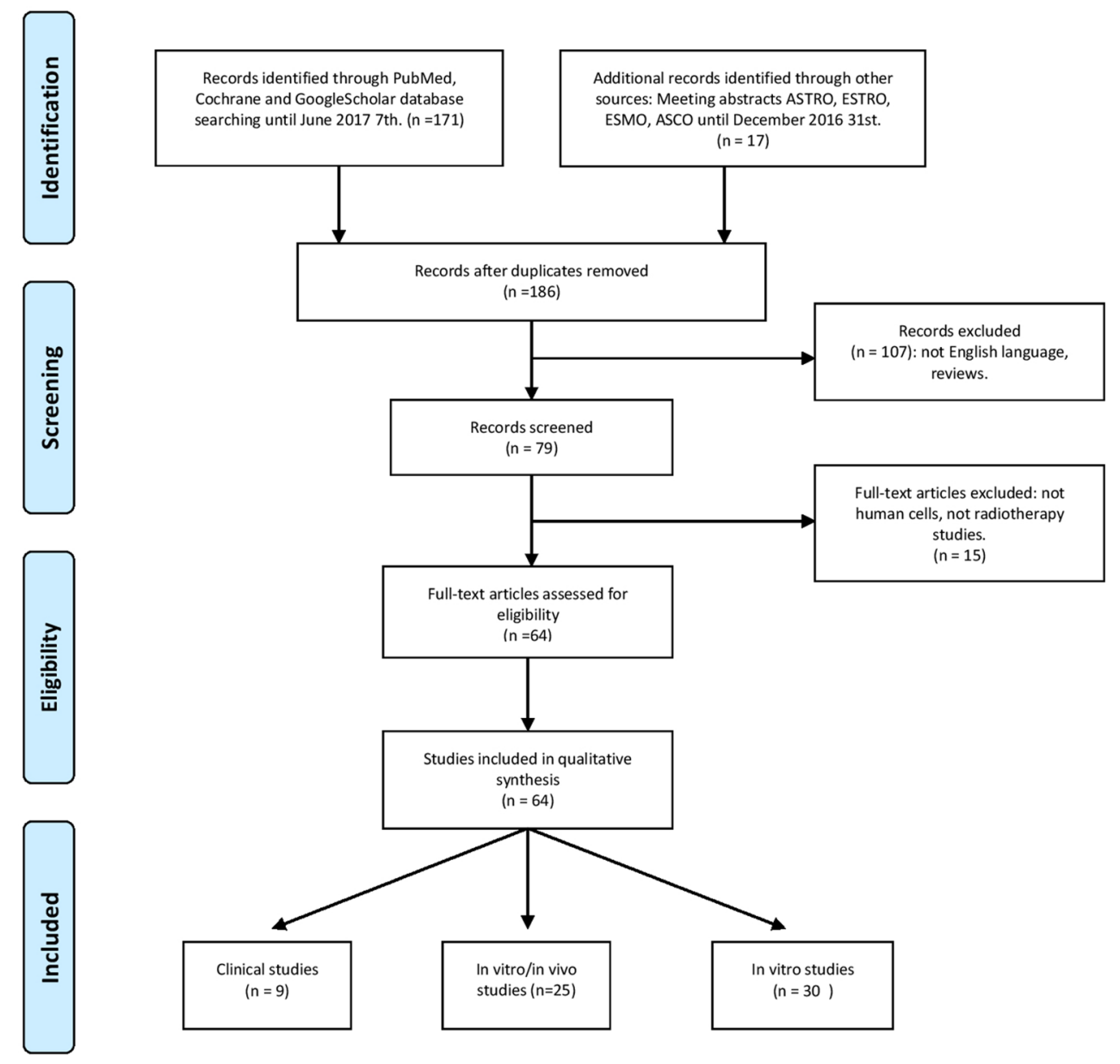

Figure 2: Flow chart of the systematic review following PRISMA guidelines. 
Table 1: PARP inhibitors and their use as radiosensitizers in pre-clinical and clinical research

\begin{tabular}{ccccc}
\hline Name & PARP Targeted & $\begin{array}{c}\text { Development as } \\
\text { radiosensitizer }\end{array}$ & $\begin{array}{c}\text { EAM /FDA } \\
\text { approved }\end{array}$ & Indication \\
\hline Olaparib & PARP1-2 & Phase I & No & None \\
Rucaparib & PARP1-2 & Pre-Clinical & No & None \\
Veliparib & PARP1-2 & Phase II & No & None \\
LT 626 & PARP-1 & Pre-clinical & No & None \\
PJ34 & PARP1-2 & Pre-clinical & No & None \\
GPI 21016 & PARP1 & Pre-Clinical & No & None \\
4-amino-1,8-naphthalimide & PARP1 & Pre-Clinical & No & None \\
3-Aminobenzamide & PARP1 & Pre-Clinical & No & None \\
Niraparib & PARP1-2 & Pre-clinical & No & None \\
\hline
\end{tabular}

thus expected in clinical studies. A phase I study has found unsafe association of veliparib with radiotherapy and TMZ for glioblastoma because of hematologic complications [45]. Concerning brain metastases, whom radiobiological characteristics are quite different of primary tumors, the association with radiotherapy seems to be safe but results are for the moment disappointing $[46,48]$.

\section{PARPi + radiotherapy for digestive system tumors}

Like for glioblastoma, radiation therapy plays an important role in the treatment of locally advanced pancreatic cancers, but its effect is limited by the sensitivity of adjacent normal tissues (Duodenum, small bowel...), and by the innate radioresistance of these cancers. Germline mutations in BRCA1/2 define a molecular subgroup of pancreatic cancers which in some populations has a prevalence as high as $17 \%$ [61]. According to these arguments, logically strategies of radiosensitization with PARPi have been developped. In vitro enhancement ratios vary from 1,2 to 1,5 with conventional radiotherapy until 1,98 with protontherapy [55-59].

Moreover, the effect of radiosensitization was greater for high LET [66].

Authors from Strasbourg laboratory are working on the combination of PARPi (olaparib) and gemcitabine after conventional and high dose photon radiation in order to radiosensitize pancreatic cancer cell lines. The first data have been obtained on three BRCA-wild type pancreatic cancer cell lines (PANC-1, AsPC-1 and MIA PaCa-2). The clonogenic survival responses showed that all cell lines could be radiosensitized with olaparib through an increase of unrepaired DSBs and a block in G2 phase. The radiosensitization with olaparib was higher than with gemcitabine. Furthermore, radiosensitization was higher with high dose per fraction. Finally, in radioresistant cell line PANC-1, olaparib and gemcitabine have a synergistic radiosensitization effect (Waissi et al. [67]). Those data are promising and need further investigations.

In vivo results are quite surprising with no increase of growth tumor delay [64, 68], and no differences between BRCA wild type and mutated tumors responses were detected. Nevertheless a phase I study is ongoing and evaluates the association of Veliparib with gemcitabine and radiotherapy for locally advanced pancreatic cancer [69]. First results should be published in 2018. Olaparib is actually investigated alone as maintenance therapy for metastatic pancreatic cancer in phase III studies [70].

Others studies concern mainly colo-rectal cancer with interesting results for in vivo studies. Combination of radiotherapy with Veliparib and Irinotecan leads to a threefold increase of growth tumor delay in Shelton et al. study [71]. The phase I study LARC, assessing association of Veliparib, Capecitabine and radiotherapy for stage IIIII rectal cancer, shows comfortable safety results with promising anti-tumor activity with respectively $72 \%, 28 \%$ and $70 \%$ for tumor downstaging, pathologic complete response and sphincter sparing surgery [72]. In conclusion, pre-clinical data show an enhancement ratio median value for pancreatic cancer equal to 1,4 and 1,45 for colo-rectal cancer (Table 3).

\section{PARPi + radiotherapy for head and neck cancers}

Current treatment regimen consists in a combination of radiotherapy with chemotherapeutics agents such as Cisplatin, 5FU, or Cetuximab and offers great effectiveness but often with unacceptable levels of toxicity [80]. Then we need studies about new radiosensitizers. Güster et al., has showed that addition of Olaparib to irradiation, for HPV positive tumors, caused substantial radiosensitization [81]. On the opposite Nickson et al., have described the best radiosensitizing effect for HPV negative cell lines with enhancement ratio reaching 3,34 [82]. PARP inhibition 
could serve as a substitute of Cisplatin, in the context of de-intensified protocols, for HPV positive head and neck tumors, so as to avoid systemic toxicity of conventional chemotherapy [81]. As for other types of tumor, HR defective cells lines are more sensitive to the combination with PARPi [83]. PARPi seem to be able to attenuate the nuclear translocation of EGF-R normally induced by DNA damages. This could lead to lower nuclear interaction between EGFR and DNA PK, and consequently lower DNA repair by c-NHEJ $[84,85]$. Median enhancement ratio obtained from pre-clinical data is 1,35 for head and neck tumors. The first phase I study, for locally advanced tumors in heavy smockers, showed promising results but follow-up is for the moment quite short [86] (Table 4).

\section{PARPi + radiotherapy for urologic cancers}

In the case of urologic cancer, PARPi are today mainly developed for prostate cancer. Relevant studies have identified genomic defects in DNA repair in 20-30\% of advanced castration-resistant prostatic cancer cases. A proportion of them are germline aberrations and heritable [91]. This is the first argument for investigating PARP inhibitors or prostate cancer treatments. After publication of high response rate in a phase II study Olaparib has been approved by FDA for the treatment of metastatic castration resistant prostate carcinoma. In this study, $88 \%$ of patients with alteration of DNA repair genes (BRCA1\&2, ATM, Fanconi anemia genes) had an objective response [91]. The second argument depends on the prevalence of TMPRSS2-ERG gene fusion in prostate cancer which has been reported to range from $40 \%$ to $70 \%$, depending on the clinical cohorts investigated [92]. This gene fusion TMPRSS2-ERG interferes with the assembly of c-NHEJ factors at DSBs on the chromatin. By inhibiting c-NHEJ via defective recruitment of XRCC4 and impaired DNAPKcs phosphorylation, TMPRSS2-ERG rearrangement may reveal a "synthetic lethal" interaction with HR, blocking repair of lesions at collapsed DNA replication forks induced by PARPi [93]. According to the different cell line, radiation enhancement ratio is comprised between 1,05 and 2,2, with much higher effects for TMPRSS2-ERG gene fusion or PTEN deficient cells. It is worth noting that for chronic hypoxia condition, which is a way of radioresistance of prostate cancer, radiosensitizing effect seems better [94]. There is not any clinical trial combining PARPi and conventional radiotherapy for the moment, but a phase $\mathrm{Ib}$ with Radium 223 and Niraparib will open soon (NCT03076203). To sum up pre-clinical studies show a median enhancement ratio of 1,3 for prostatic cancer (Table 5).

\section{PARPi + radiotherapy for lung cancers}

A third of non small cell lung cancers (NSCLC) patients are diagnosed at a locally advanced stage.
Radiation therapy instead of surgery is so a standard of care $\mathrm{t}$ for these patients. Despite technical advances in radiation therapy, the local tumor control remains suboptimal due to radioresistance. Multiple in vitro and in vivo studies have been realized, assessing potential role of PARPi as radio sensitizer. Enhancement ratio values are comprised between 1,1 and 1,62 with modern PARP inhibitors under oxia $\left(21 \% \mathrm{O}_{2}\right)$ conditions for NSCLC. Under hypoxia conditions, which is closer to the clinical reality, enhancement ratio reaches 2,87 suggesting that hypoxia $\left(1 \% \mathrm{O}_{2}\right)$ induces contextual synthetic lethality with PARP inhibition in vitro [103]. Small cell lung cancer (SCLC) cell lines, which show a high expression level of PARP-1 [104], are also radio sensitized by PARPi [105]. Albert et al., showed a decrease in in vitro endothelial tubule formation with Veliparib/radiation combination treatment, and revealed decreased vessel formation in vivo, suggesting that, this strategy may also target tumor angiogenesis [106]. Few phase I clinical trials are actually recruiting patients. In conclusion pre-clinical data show a median enhancement ratio of 1,5 for lung cancer (Table 6).

\section{PARPi + radiotherapy for breast and gynaecologic cancers}

With ovary cancer, breast cancer is the most known tumor to get BRCA1 or 2 mutations, and is thus a candidate for PARPi radiosensitization. Nevertheless, surprisingly, PARP1 inhibition improves the therapeutic index of radiotherapy independent of breast cancer subtype or BRCA1 mutational status. Among breast cancer subtypes, HER2 and luminal cancer cells seem to get better enhancement ratio [110]. While it remains dogma that IR and genotoxic agents mediate their lethal effects via enhanced apoptosis, necrosis or mitotic catastrophe, Efimova et al. showed that for Breast cancer cell lines PARP inhibitors may have a significant impact by inducing senescence [111]. Median value of enhancement ratio induced by PARPi for breast cancer is 1,36. The safety datas of phase I study of Jagsi et al. about loco regional radiotherapy for local recurrence of Triple negative breast cancer are comforting, with one unexpected grade IV toxicity on 30 patients [112] (Table 7).

\section{PARPi + radiotherapy for rare cancers}

Few authors expressed an interest in rare tumors such as Ewing sarcoma and have obtained promising preclinical results, but data stay poor $[107,114]$. It is also the case for chondrosarcoma which is however considered as one of the most radioresistant tumor. Our laboratory is working on combination of PARPi (AG15361, Olaparib, and Talazoparib) and conventional radiotherapy, protontherapy or hadrontherapy in order to radiosensitize chondrosarcoma cells. First data with conventional radiotherapy are very interesting and deserve further 
Table 2: Studies concerning PARPi radiosensitization for brain tumors

\begin{tabular}{|c|c|c|c|c|c|}
\hline \multicolumn{6}{|c|}{ Brain system } \\
\hline Cell lines / tumor & Phase & PARP Inhibitor & ER & Comments & Ref \\
\hline $\begin{array}{l}\text { Glioma cell lines (T98G } \\
\text { and U373-MG) }\end{array}$ & In vitro & PJ34 (3 $\mu \mathrm{M})$ & $\begin{array}{c}\text { Yes } \\
\text { (not communicated) }\end{array}$ & $\begin{array}{l}\text { T98G sensitized by PJ34 to a } \\
\text { range of low doses } \\
\text { of radiation. U373-MG } \\
\text { cells showed no increase of } \\
\text { radiosensitivity for } \\
\text { low-dose range ( } 1 \mathrm{~Gy}) \text {. }\end{array}$ & {$[35]$} \\
\hline $\begin{array}{l}\text { Glioma cell lines } \\
\text { (T98G, U373-MG, U87- } \\
\text { MG,UVW) }\end{array}$ & In vitro & Olaparib $(1 \mu \mathrm{M})$ & 1,08 to 1,38 & $\begin{array}{l}\text { Radiosensitization is replication } \\
\text { dependent and greater for } \\
\text { fractionated than for single-dose } \\
\text { treatments }\end{array}$ & {$[16]$} \\
\hline $\begin{array}{c}\text { Glioma cell lines } \\
\text { (M059J and M059K) }\end{array}$ & In vitro & 4-amino-1,8-naphthalimide $(30 \mu \mathrm{M})$ & No & $\begin{array}{l}\text { No significant increase of } \\
\text { radiosensistivity }\end{array}$ & {$[15]$} \\
\hline $\begin{array}{l}\text { Glioma cell line } \\
\text { (U251) }\end{array}$ & $\begin{array}{l}\text { In vitro } \\
\text { In vivo }\end{array}$ & $\begin{array}{c}\text { In vitro GPI-21016(3 } \mu \mathrm{M}) \text {. In Vivo } \\
\mathrm{GPI}-21016(40 \mathrm{mg} / \mathrm{kg})+\mathrm{TMZ}(3 \\
\mathrm{mg} / \mathrm{kg})\end{array}$ & 1,6 & $\begin{array}{l}\text { In vivo: Absolute growth delay } \\
\qquad 31 \mathrm{~d}(1,53 \mathrm{x})\end{array}$ & {$[36]$} \\
\hline $\begin{array}{l}\text { Glioma cell lines } \\
\text { (SF188 and KNS42) }\end{array}$ & In vitro & Olaparib $(0-8 \mu \mathrm{M})$ & $\begin{array}{c}\text { Yes } \\
\text { (not communicated) }\end{array}$ & Regression of cell Proliferation & {$[37]$} \\
\hline $\begin{array}{l}\text { Glioma cell lines } \\
\text { (T98G, LN18, U87 and } \\
\text { U251) }\end{array}$ & In vitro & Veliparib $(5 \mu \mathrm{M})+\mathrm{TMZ}(5-10 \mu \mathrm{M})$ & $\begin{array}{c}1,13 \text { to } 1,37 \text { (Veliparib). } \\
1,25 \text { to } 1,44 \\
\text { (Veliparib+TMZ) }\end{array}$ & $\begin{array}{l}\text { Also measured in one of the } \\
\text { MGMT-unmethylated cell lines } \\
\text { with a SER } 50 \text { value of } 1.30\end{array}$ & {$[38]$} \\
\hline $\begin{array}{l}\text { Glioma cell lines } \\
\text { (UVW/NAT) }\end{array}$ & In vitro & Rucaparib $(1 \mu \mathrm{M}) /$ Olaparib $(1 \mu \mathrm{M})$ & $\begin{array}{l}\text { Rucaparib } 1,33 \\
\text { Olaparib } 1,91\end{array}$ & $\begin{array}{l}\text { PARP-1 inhibition in } \\
\text { combination with } \mathrm{X} \text {-irradiation } \\
\text { promoted } \mathrm{G} 2 / \mathrm{M} \text { arrest }\end{array}$ & {$[39]$} \\
\hline $\begin{array}{l}\text { Glioblastoma cell lines } \\
\text { derived from patients } \\
\text { tumors (MGMT } \\
\text { unmethylated) }\end{array}$ & $\begin{array}{l}\text { In vitro } \\
\text { In vivo }\end{array}$ & $\begin{array}{c}\text { Veliparib }(10 \mu \mathrm{M}) \\
\text { Veliparib }(12,5 \mathrm{mg} / \mathrm{kg} 2 \mathrm{x} / \mathrm{d})\end{array}$ & $\begin{array}{c}\text { Yes } \\
\text { (not communicated) }\end{array}$ & $\begin{array}{l}\text { Significant increase of mouse } \\
\text { survival (+ 10days })\end{array}$ & {$[40]$} \\
\hline $\begin{array}{l}\text { Primary patient-derived } \\
\text { glioblastoma cell lines }\end{array}$ & In vitro & Olaparib (not available) & $\begin{array}{l}1,93 \text { for Cancer Stem } \\
\text { cells } \\
1,34 \text { for bulk cells }\end{array}$ & $\begin{array}{l}\text { No significant difference } \\
\text { between bulk and stem cells. }\end{array}$ & {$[41]$} \\
\hline $\begin{array}{l}\text { Pediatric Glioma cell } \\
\text { lines (SJG2, SF188, } \\
\text { KNS42 ) }\end{array}$ & $\begin{array}{l}\text { In vitro } \\
\text { In vivo }\end{array}$ & $\begin{array}{c}\text { Niraparib }(1 \mu \mathrm{M}) \\
\text { Niraparib }(50 \mathrm{mg} / \mathrm{kg})\end{array}$ & $\begin{array}{c}\text { Yes } \\
\text { (not communicated) }\end{array}$ & $\begin{array}{l}\text { Significant decrease of survival } \\
\text { fraction. In vivo survival : } 1,6 \mathrm{x} \\
\text { longer }\end{array}$ & {$[42]$} \\
\hline $\begin{array}{c}\text { DIPG cell lines } \\
\text { (DIPGM36 DIPG58, and } \\
\text { SU-DIPG-IV) }\end{array}$ & In vitro & Niraparib (1 $\mu \mathrm{M})$ & $\begin{array}{c}\text { Yes } \\
\text { (not communicated) }\end{array}$ & $\begin{array}{l}\text { Significant decrease of survival } \\
\text { fraction. }\end{array}$ & {$[42]$} \\
\hline $\begin{array}{l}\text { Ependymoma cell line } \\
\text { (Res196) }\end{array}$ & In vitro & Olaparib $(0-8 \mu \mathrm{M})$ & $\begin{array}{c}\text { Yes } \\
\text { (not communicated) }\end{array}$ & $\begin{array}{l}\text { Regression of cell Proliferation. } \\
\text { Decrease of clonogenic survival }\end{array}$ & {$[37]$} \\
\hline $\begin{array}{l}\text { Medulloblastoma cell lines } \\
\text { (D283-med, D556-med } \\
\text { and UW228-2) }\end{array}$ & In vitro & Olaparib $(0-8 \mu \mathrm{M})$ & $\begin{array}{c}\text { Yes } \\
\text { (not communicated) }\end{array}$ & $\begin{array}{l}\text { Persistance of } \gamma \mathrm{H} 2 \mathrm{AX} \text { foci } \\
\text { up to } 72 \text { hours after radiation. } \\
\text { Regression of cell proliferation }\end{array}$ & {$[37]$} \\
\hline $\begin{array}{c}\text { Neuroblastoma cell } \\
\text { lines (SH-SY-5Y, Kelly, } \\
\text { NB1691luc and Tet 21) }\end{array}$ & $\begin{array}{l}\text { In vivo } \\
\text { In vitro }\end{array}$ & Nirabarib (50 mg/kg) & $\begin{array}{c}\text { Yes } \\
\text { (not communicated) }\end{array}$ & In vivo Survival: $\approx 1,08 \times$ longer & {$[43]$} \\
\hline $\begin{array}{l}\text { Neuroblastoma cell lines } \\
\quad(\mathrm{SK}-\mathrm{N}-\mathrm{BE}(2 \mathrm{c}))\end{array}$ & In vitro & $\begin{array}{l}\text { Rucaparib(1 } \mu \mathrm{M}) \\
\text { Olaparib }(1 \mu \mathrm{M})\end{array}$ & $\begin{array}{l}\text { Rucaparib } 1,05 \\
\text { Olaparib } 1,09\end{array}$ & $\begin{array}{l}\text { PARP-1 inhibition in } \\
\text { combination with } \mathrm{X} \text {-irradiation } \\
\text { promoted } \mathrm{G} 2 / \mathrm{M} \text { arrest }\end{array}$ & [39] \\
\hline $\begin{array}{l}\text { Neuroblastoma cell } \\
\text { (HX142c) }\end{array}$ & In vitro & 3 amino benzamide $(6 \mathrm{mM})$ & 1,18 & No impact of dose rate. & {$[44]$} \\
\hline Glioblastoma & Phase I & $\begin{array}{c}\text { Veliparib (10 mg bid) }+ \text { TMZ(75 } \\
\mathrm{mg} / \mathrm{m} 2)\end{array}$ & not applicable & Only safety results. & {$[45]$} \\
\hline $\begin{array}{l}\text { All histologies Brain } \\
\text { metastases }\end{array}$ & Phase I & $\begin{array}{l}\text { Veliparib (escalating doses of } \\
10-300 \mathrm{mg} \text { bid ) + Whole brain } \\
\text { radiotherapy }\end{array}$ & not applicable & OS: $10 \mathrm{~m} \mathrm{Vs} 3,5 \mathrm{~m}$ & {$[46]$} \\
\hline $\begin{array}{l}\text { Diffuse intrinsic pontine } \\
\text { glioblastoma }\end{array}$ & Phase I-II & $\begin{array}{c}\text { Veliparib } 65 \mathrm{mg} / \mathrm{m} 2+\text { radiotherapy } \\
\text { followed with adjuvant } \mathrm{TMZ}+ \\
\text { veliparib }(25 \mathrm{mg} / \mathrm{m} 2)\end{array}$ & not applicable & $\begin{array}{l}\text { OS: } 1 \text { year } 29 \%, 2 \text { year } 11 \% \text {. } \\
\text { Well tolerated. No benefit. }\end{array}$ & {$[47]$} \\
\hline NSCLC Brain metastases & $\begin{array}{c}\text { Randomized } \\
\text { phase II }\end{array}$ & $\begin{array}{c}\text { Veliparib(50 mg/200 mg/placebo) } \\
+ \text { WBRT }\end{array}$ & not applicable & OS: 209d Vs 185d ( NS) & {$[48]$} \\
\hline
\end{tabular}


Table 3: Studies concerning PARPi radiosensitization for digestive system tumors

\begin{tabular}{|c|c|c|c|c|c|}
\hline \multicolumn{6}{|c|}{ Digestive tract } \\
\hline Cell lines / tumor & Phase & PARP Inhibitor & ER & Comments & Ref \\
\hline $\begin{array}{l}\text { Colorectal cancer cell } \\
\text { lines }(\text { LoVo, SW620) }\end{array}$ & $\begin{array}{l}\text { In vitro } \\
\text { In vivo }\end{array}$ & $\begin{array}{c}\text { AG14361 } 0,4 \mu \mathrm{M} \\
\text { AG14361 } 15 \mathrm{mg} / \mathrm{kg} / \text { day }\end{array}$ & Yes (not communicated) & $\begin{array}{l}\text { Until additional } 18 \mathrm{~d} \text { of delay } \\
\text { in tumor growth }\end{array}$ & [73] \\
\hline $\begin{array}{l}\text { Colorectal cancer cell } \\
\text { lines (HCT116) }\end{array}$ & In vivo & Veliparib (25 mg/kg/day) & Not applicable & $\begin{array}{l}\text { Median survival time } \\
\text { increased from } 23 \text { to } 36 \text { days }\end{array}$ & [60] \\
\hline $\begin{array}{l}\text { Colorectal cancer cell } \\
\text { lines (HCT116) }\end{array}$ & In vitro & Olaparib $(1 \mu \mathrm{M})$ & Yes (not communicated) & $\begin{array}{l}\text { No radiosensitization of } \\
\text { normal intestinal cell line. } \\
\text { Increased } \\
\text { effect with Combined Chk1 } \\
\text { inhibitor }\end{array}$ & [65] \\
\hline $\begin{array}{l}\text { Colorectal cancer cell } \\
\text { line (DLD-1) }\end{array}$ & In vitro & $\begin{array}{l}\text { Olaparib }(1 \mu \mathrm{M})+/- \\
\text { Camptothecine }\end{array}$ & $\begin{array}{l}1,20 \text { (alone) to } 1,45 \\
\text { (combination) }\end{array}$ & $\begin{array}{l}\text { Increase of } \mathrm{G} 2 / \mathrm{M} \text { phase cells } \\
\text { and reduced } \mathrm{S} \text { phase cells. }\end{array}$ & [74] \\
\hline $\begin{array}{l}\text { Colorectal cancer cell } \\
\text { lines (HCT116) }\end{array}$ & $\begin{array}{l}\text { In vitro } \\
\text { In vivo }\end{array}$ & $\begin{array}{c}\text { Veliparib }(5 \mu \mathrm{M})+ \\
\text { Irinotecan or oxaliplatine } \\
\text { or } 5 \mathrm{FU}\end{array}$ & $\begin{array}{l}\text { In vitro: enhanced ratio } \\
1.60 \text { to } 1,82\end{array}$ & $\begin{array}{l}\text { Until additional } 11 \mathrm{~d} \text { of delay } \\
\text { in tumor growth }\end{array}$ & [71] \\
\hline $\begin{array}{l}\text { Colorectal cancer cell } \\
\text { lines (HCT116) }\end{array}$ & In vitro & $\begin{array}{l}\text { Olaparib and Niraparib (1 } \\
\qquad \mu \mathrm{M})\end{array}$ & Yes (not communicated) & $\begin{array}{l}\text { Reduction of clonogenic } \\
\text { survival. Increased autophagy } \\
\text { and senescence, but not } \\
\text { apoptosis. }\end{array}$ & {$[75]$} \\
\hline $\begin{array}{c}\text { Pancreatic cancer cell } \\
\text { lines (Miapaca-2) }\end{array}$ & In vitro & In vitro GPI-21016 (3 $\mu \mathrm{M})$ & 1,4 & None & {$[36]$} \\
\hline $\begin{array}{c}\text { Pancreatic cancer } \\
\text { cell lines (Miapaca-2, } \\
\text { MPanc-96) }\end{array}$ & In vitro & Olaparib $(1 \mu \mathrm{M})$ & 1,5 & $\begin{array}{l}\text { Increased effect with } \\
\text { Combined Chk1 inhibitor }\end{array}$ & [65] \\
\hline $\begin{array}{l}\text { Pancreatic cancer cell } \\
\text { lines (Miapaca-2) }\end{array}$ & In vitro & Olaparib $(1 \mu \mathrm{M})$ & $\begin{array}{c}\text { Low LET }(\gamma): 1,4 \\
\text { High LET (Carbon } \\
\text { 13keV/um): 1,2 High LET } \\
(\text { Carbon } 70 \mathrm{keV} / \mathrm{um}): 1,4\end{array}$ & $\begin{array}{c}\text { Enhancement ratio reaches } \\
2,5 \text { with } 5 \mu \mathrm{M} \text { and High LET } \\
\text { radiation }\end{array}$ & [63] \\
\hline $\begin{array}{l}\text { Pancreatic cancer cell } \\
\text { lines (MiaPaCa-2, } \\
\text { Panc-1,Capan-1, } \\
\text { AsPC-1) }\end{array}$ & In vitro & $\begin{array}{c}\text { Rucaparib }(1 \mu \mathrm{M})+ \\
\text { Gemcitabine }\end{array}$ & Enhanced ratio: present & $\begin{array}{l}\text { Best ratio for BRCA2 mutated } \\
\text { Capan-1 cell line. }\end{array}$ & [62] \\
\hline $\begin{array}{c}\text { Pancreatic } \\
\text { cancer cell lines } \\
(\mathrm{MiaPaCa} 2, \mathrm{AsPC}-1)\end{array}$ & $\begin{array}{l}\text { In Vitro } \\
\text { In Vivo }\end{array}$ & $\begin{array}{c}\text { Olaparib }(1 \mu \mathrm{M}) \\
\text { Olaparib }(60 \mathrm{mg} / \mathrm{kg})\end{array}$ & $\begin{array}{l}1,2 \text { for } \mathrm{MiaPaCa} 2 \\
1,2 \text { for } \mathrm{AsPC}-1 \text {. }\end{array}$ & $\begin{array}{l}\text { No difference for tumor } \\
\text { growth delay. }\end{array}$ & [64] \\
\hline $\begin{array}{l}\text { Pancreatic cancer cell } \\
\text { lines (OCIP 23, OCIP } \\
28)\end{array}$ & In vivo & Olaparib (150 mg/kg) & Not applicable & $\begin{array}{l}\text { No difference for tumor } \\
\text { growth delay. No } \\
\text { radiosensitization observed in } \\
\text { the BRCA2 germline mutant } \\
\text { tumor }\end{array}$ & [68] \\
\hline $\begin{array}{l}\text { Pancreatic cancer cell } \\
\text { lines (Miapaca2, PDA) }\end{array}$ & $\begin{array}{l}\text { In vitro } \\
\text { In vivo. }\end{array}$ & LT $626(10 \mu \mathrm{M})$ & Yes (not communicated) & $\begin{array}{l}\text { Synergic effect on } \\
\text { Isobolograms }\end{array}$ & [76] \\
\hline $\begin{array}{c}\text { Pancreatic cancer cell } \\
\text { lines (Miapaca-2) }\end{array}$ & In vitro & $\begin{array}{l}\text { Olaparib }(5 \mu \mathrm{M})+ \\
\text { Protontherapy }\end{array}$ & $\begin{array}{l}1,59 \text { at entrance region } \\
1,98 \text { in the bragg Peak }\end{array}$ & Increased $\mathrm{G} 2 / \mathrm{M}$ arrest & [66] \\
\hline $\begin{array}{l}\text { Hepatocarcinoma cell } \\
\text { lines (HepG2, PLC- } \\
\text { PRF-5) }\end{array}$ & In vitro & Veliparib $(10 \mu \mathrm{M})$ & $\begin{array}{c}1,48 \text { for HepG2 } \\
1,17 \text { for PLC-PRF-5 }\end{array}$ & None & [77] \\
\hline $\begin{array}{l}\text { Locally advanced } \\
\text { rectal cancer }\end{array}$ & Phase Ib & $\begin{array}{c}\text { Veliparib }+ \text { Capecitabine } \\
\text { + RT }\end{array}$ & Not applicable & $\begin{array}{l}\text { Tumor downstaging } 71 \% \text { of } \\
31 \text { evaluable pts; Pathologic } \\
\text { complete response } 29 \% \text {. } \\
\text { Acceptable safety profile. }\end{array}$ & [78] \\
\hline $\begin{array}{l}\text { Locally advanced } \\
\text { pancreatic cancer }\end{array}$ & Phase I & $\begin{array}{c}\text { Veliparib }+ \text { Gemcitabine }+ \\
\text { RT }\end{array}$ & Not applicable & Safety data & [69] \\
\hline $\begin{array}{l}\text { Advanced solid } \\
\text { tumors and } \\
\text { carcinomatosis }\end{array}$ & Phase I & $\begin{array}{l}\text { Veliparib + whole } \\
\text { abdominal RT }\end{array}$ & Not applicable & $\begin{array}{l}3 \% \text { objective response. No } \\
\text { significant. }\end{array}$ & [79] \\
\hline
\end{tabular}


Table 4: Studies concerning PARPi radiosensitization for head and neck tumors

\begin{tabular}{|c|c|c|c|c|c|}
\hline \multicolumn{6}{|c|}{ Head and neck tract } \\
\hline Cell lines/tumor & Phase & PARP Inhibitor & ER & Comments & Ref \\
\hline $\begin{array}{l}\text { HNSCC cell lines } \\
\text { (JHU006 and JHU012) }\end{array}$ & In vitro In vivo & GPI-21016 (7 $\mu \mathrm{M})$ & Yes ( not communicated) & $\begin{array}{l}\text { Apoptotis increased of } \\
51 \% \text { for the combinated } \\
\text { treatment versus } \\
\text { radiotherapy alone. } \\
\text { Significant inhibition of } \\
\text { tumor growth. }\end{array}$ & [87] \\
\hline $\begin{array}{l}\text { HNSCC cell lines (UM- } \\
\text { SCC1, UM-SCC5, UM- } \\
\text { SCC6, Fadu) }\end{array}$ & In vitro & Veliparib $(1-10 \mu \mathrm{M})$ & Yes ( not communicated) & $\begin{array}{l}\text { Combination Reduced } \\
\text { colony forming ability } \\
\text { of cells by } 70-95 \% \mathrm{Vs} \\
30-40 \% \text { with radiotherapy } \\
\text { alone. }\end{array}$ & [84] \\
\hline $\begin{array}{l}\text { Human HNSCC cell lines } \\
\text { (UTSCC5, UTSCC8, } \\
\text { UTSCC14, UTSCC15, } \\
\text { UTSCC45, FaDu, Cal33, } \\
\text { SAS, HSC4 and XF354) }\end{array}$ & In vitro & Olaparib $(1 \mu \mathrm{M})$ & 1,35 to 1,61 & $\begin{array}{l}1,61 \text { for HR deficient cells } \\
1,35 \text { for HR efficient cells }\end{array}$ & [83] \\
\hline $\begin{array}{l}\text { HNSCC HPV-p16+ cancer } \\
\text { cell lines (93-VU-147T, } \\
\text { UM-SCC-47, UTSCC- } \\
\text { 45,UD-SCC-2, UPCI- } \\
\text { SCC-154) }\end{array}$ & In vitro & Olaparib $(1 \mu \mathrm{Mz})$ & Yes (not communicated) & $\begin{array}{l}\text { On contrast to cetuximab, } \\
\text { the addition of the } \\
\text { PARP inhibitor olaparib } \\
\text { resulted in a substantial } \\
\text { radiosensitization of all } \\
\operatorname{HPV}(+) \text { cell lines. }\end{array}$ & [81] \\
\hline $\begin{array}{c}\text { HNSCC cancer cell lines } \\
\text { (UT-SCC-12A, UT-SCC- } \\
\text { 20A,UT-SCC-24B, UT- } \\
\text { SCC-30, UT-SCC-45 and } \\
\text { UT-SCC-60B) }\end{array}$ & In vitro & Olaparib $(1 \mu \mathrm{M})$ & 1,11 to 1,61 & $\begin{array}{l}\text { Extent of radiosensitization } \\
\text { depends on olaparib dose } \\
\text { and BRCA2 status }\end{array}$ & [88] \\
\hline $\begin{array}{c}\text { Oropharynx HNSCC } \\
\text { cancer cell lines } \\
\text { (UMSCC6, UMSCC74, } \\
\text { UMSCC47, UPCI- } \\
\text { SCC090) }\end{array}$ & In vitro & Olaparib $(0,1 \mu \mathrm{M})$ & $\begin{array}{c}\text { 1,51 for UMSCC47 } \\
3,34 \text { for UMSCC6 } \\
1,74 \text { for UMSCC74A }\end{array}$ & $\begin{array}{l}\text { Better results for HPV-cell } \\
\text { lines. }\end{array}$ & [82] \\
\hline $\begin{array}{c}\text { Nasopharyngeal } \\
\text { carcinoma cell lines } \\
\text { (C666-1, CNE2, HNE1, } \\
\text { HONE1) }\end{array}$ & In vitro In Vivo & $\begin{array}{c}\text { Olaparib }(1 \mu \mathrm{M}) \text { Olaparib } \\
\qquad(50 \mathrm{mg} / \mathrm{kg})\end{array}$ & Yes (not communicated) & $\begin{array}{l}\text { Strong tumor inhibitory } \\
\text { effect in xenograft } \\
\text { models. No synergism on } \\
\text { nasopharyngeal epithelial } \\
\text { cells }\end{array}$ & [89] \\
\hline $\begin{array}{c}\text { Nasopharyngeal } \\
\text { carcinoma cell lines } \\
\text { (CNE2) }\end{array}$ & In vitro & 3 Amino Benzamide & Yes (not communicated) & $\begin{array}{l}\text { Increases the apoptosis } \\
\text { rate from } 27 \text { for radiation } \\
\text { alone to } 31 \% \text { for } \\
\text { combination treatment. } \\
\text { Significant decrease of } \\
\text { proliferation rate }\end{array}$ & [90] \\
\hline $\begin{array}{c}\text { Heavy smokers with LA- } \\
\text { HNSCC }\end{array}$ & Phase I & $\begin{array}{c}\text { Olaparib + Cetuximab }+ \\
\text { IMRT }\end{array}$ & Not applicable & $\begin{array}{l}\text { Median follow up : } 14 \\
\text { months. } 3 \text { recurrences. } \\
\text { Toxicity acceptable }\end{array}$ & [86] \\
\hline
\end{tabular}

investigations. All clonogenic survival data with olaparib showed radiosensitization of Oums 27 or $\mathrm{CH} 2879$ cell lines (PTCOG 2016, Chevalier et al. [115]). There are still on going investigations (Figure 3 ).

\section{DISCUSSION}

Radiation therapy plays a central role in cancer therapeutics, as an adjuvant therapy and above all as first treatment, alone or with radiosensitizer, for lowoperable tumors such as glioblastoma or advanced lung cancers. Nevertheless, cure rates stay disappointing, and concomitant chemotherapy generate important systemic toxicity, requiring search for new radiosensitizers. Ideal radiosensitizing agents should have two main qualities: on the first hand to offer better protection to surround healthy tissues, on the other hand, to increase anti tumoral efficiency, with hope to improve therapeutic ratio. Since the last ten years PARP seems to be one of the most interesting protein to target, in association with radiotherapy because particularly of its role in DNA repair. We have reported more than fifty in vitro or in vivo studies which have investigated PARPi as radiosensitizer with attractive enhancement ratio comprised 
Table 5: Studies concerning PARPi radiosensitization for prostate tumors

\begin{tabular}{|c|c|c|c|c|c|}
\hline \multicolumn{6}{|c|}{ Urologic cancer } \\
\hline Cell lines / tumor & Phase & PARP Inhibitor & ER & Comments & Ref \\
\hline $\begin{array}{l}\text { Prostate carcinoma cell } \\
\text { lines (DU145) }\end{array}$ & In vitro & $\begin{array}{l}\text { 4-amino-1,8-naphthalimide } \\
\text { (ANI) }(20 \mu \mathrm{M})\end{array}$ & 1,3 & None & [95] \\
\hline $\begin{array}{l}\text { Prostate carcinoma cell } \\
\text { lines (DU145) }\end{array}$ & In vitro & In vitro GPI-21016 $(5 \mu \mathrm{M})$ & 1,7 & None & [36] \\
\hline $\begin{array}{l}\text { Prostate carcinoma cell } \\
\text { lines (DU145, 22RV1) }\end{array}$ & In vitro & Veliparib $(2,5 \mu \mathrm{M})$ & 1, 25 ( Under Hypoxia) & $\begin{array}{c}\text { SF2 of DU145 and 22RV1 } \\
\text { cells decreased from } 0.44 \\
\text { and } 0.36 \text { to } 0.27 \text { and } 0.20, \\
\text { respectively. }\end{array}$ & [96] \\
\hline $\begin{array}{l}\text { Prostate carcinoma cell } \\
\text { lines (PC3, DU145) }\end{array}$ & $\begin{array}{l}\text { In vitro } \\
\text { In vivo }\end{array}$ & $\begin{array}{c}\text { Veliparib }(10 \mu \mathrm{M}) \text { Veliparib } \\
\qquad(25 \mathrm{mg} / \mathrm{kg})\end{array}$ & Yes ( Not communicated) & $\begin{array}{l}\text { More Significant decrease } \\
\text { of survival fraction for } \\
\text { PC3 thant DU-145 in vitro. } \\
\text { Significant delay in tumor } \\
\text { regrowth only for PC3. }\end{array}$ & [97] \\
\hline $\begin{array}{l}\text { Prostate carcinoma cell } \\
\text { lines (PC3, DU145, } \\
\text { LNCaP,VCaP) }\end{array}$ & In vitro & Rucaparib $(\leq 2,5 \mu \mathrm{M})$ & Yes ( Not communicated) & $\begin{array}{l}\text { More effective for PTEN } \\
\text { deficient cells or with } \\
\text { TMPRSS2-ERG gene fusion }\end{array}$ & [98] \\
\hline $\begin{array}{l}\text { Prostate carcinoma cell } \\
\text { lines (PC3, DU145) }\end{array}$ & $\begin{array}{l}\text { In vitro } \\
\text { In vivo }\end{array}$ & $\begin{array}{c}\text { Olaparib }(1 \mu \mathrm{M}) \text { Olaparib } \\
\qquad(100 \mathrm{mg} / \mathrm{kg})\end{array}$ & 1,12 to 1,52 & $\begin{array}{l}1,12 \text { for ERG-, } 1,52 \text { for } \\
\text { Erg+. In vivo radioresistance } \\
\text { in ERG+ can be overcome } \\
\text { through inhibition of PARP1. }\end{array}$ & [99] \\
\hline $\begin{array}{l}\text { Prostate carcinoma cell } \\
\text { lines (LNCaP) }\end{array}$ & In vitro & Niraparib $(1 \mu \mathrm{M})$ & 1,43 & $\begin{array}{c}\text { Did not radiosensitize } \\
\text { human cells derived from } \\
\text { normal tissues }\end{array}$ & {$[100]$} \\
\hline $\begin{array}{l}\text { Prostate carcinoma cell } \\
\text { lines (PC3, DU145, } \\
\text { LNCaP) }\end{array}$ & In vitro & Olaparib $(1 \mu \mathrm{M})$ & $\begin{array}{c}1,05 \text { for DU } 145 \text { (NS) } \\
\text { 1, } 3 \text { to } 2,2 \text { for PC3, } \\
\text { LNCAP. }\end{array}$ & $\begin{array}{l}\text { In non-responders, the } \\
\text { induced DSBs are repaired } \\
\text { exclusively by NHEJIn } \\
\text { responders, PARP1-EJ shares } \\
\text { NHEJ in repairing the DSBs } \\
\text { induced after IR }\end{array}$ & [101] \\
\hline $\begin{array}{l}\text { Prostate carcinoma cell } \\
\text { line }(22 \mathrm{Rv} 1)\end{array}$ & $\begin{array}{l}\text { In vitro } \\
\text { In vivo }\end{array}$ & $\begin{array}{c}\text { Olaparib }(1 \mu \mathrm{M}) \text { Olaparib } \\
(100 \mathrm{mg} / \mathrm{kg})\end{array}$ & 1,7 & $\begin{array}{l}1,2 \text { under acute Hypoxia, } \\
1,8 \text { under chronic hypoxia. } \\
\text { In vivo : Growth delay } \\
\text { increased of } 6,06 \text { days }(\mathrm{ns})\end{array}$ & [94] \\
\hline $\begin{array}{l}\text { Prostate carcinoma cell } \\
\text { lines }(\mathrm{PC} 3, \mathrm{LNCaP})\end{array}$ & In vitro & Rucaparib $(2,5 \mu \mathrm{M})$ & Yes ( Not communicated) & $\begin{array}{c}\text { Most effective for } \\
\text { TMPRSS2-ERG gene fusion } \\
\text { cells }\end{array}$ & [93] \\
\hline $\begin{array}{l}\text { Prostate carcinoma cell } \\
\text { lines }(\mathrm{PC} 3, \mathrm{VCaP})\end{array}$ & In vitro & $\begin{array}{c}\text { Rucaparib }(3 \mu \mathrm{M}) \text {, Olaparib } \\
(3 \mu \mathrm{M})\end{array}$ & Yes ( Not communicated) & $\begin{array}{c}\mathrm{SF} 2 \text { from } 0,50 \text { to } 0,12 \text { for } \\
\text { olaparib SF2 from } 0,45 \text { to } 0 \text {, } \\
13 \text { for rucaparib }\end{array}$ & [102] \\
\hline
\end{tabular}

between 1,04 and 2,87 for in vitro data (Tables 2-7), PARPi could even bypass some radioresistant mechanisms such as hypoxia $[96,103]$. Nevertheless, in vivo results are often less promising, and only 9 phase I-II studies get published results, sometimes negative. Nine other phase I-II clinical trials (clinicaltrials.gov) are actually recruiting, all using Olaparib or Veliparib in combination with radiotherapy or radio-chemotherapy for soft tissue sarcoma, breast cancer, lung cancer, rectal cancer or esophageal cancer. During the 2 or 3 next years, they should bring some new information concerning the potential of PARPi as radiosensitizer.
It is important to note that, combination treatment appears to promote a state of growth arrest instead of cell death, it is legitimate to speculate that radiosensitization could be a consequence of an increase in the extent of senescence $[75,97,111]$. The next critical question is whether the growth arrest is sustained and irreversible or transient and reversible, and consequently if this combination approach is so useful for improving long-term endpoints.

A current interrogation remains that radiosensitizing effect on high proliferating non tumoral tissues, like mucosa or bone marrow, is quite unknown. Effectively in vitro studies including investigations with normal cells 
Table 6: Studies concerning PARPi radiosensitization for lung tumors

\begin{tabular}{|c|c|c|c|c|c|}
\hline \multicolumn{6}{|c|}{ Lung cancer } \\
\hline Cell lines / tumor & Phase & PARP Inhibitor & ER & Comments & Ref \\
\hline NSCLC cell lines & In vitro & $\begin{array}{l}3 \text { amino benzamide } \\
(8 \mathrm{mM})\end{array}$ & No & None & {$[107]$} \\
\hline $\begin{array}{l}\text { NSCLC cell lines } \\
(\text { HX147c) }\end{array}$ & In vitro & $\begin{array}{l}3 \text { amino benzamide } \\
(8 \mathrm{mM})\end{array}$ & No & $\begin{array}{l}\text { Absence of radiosensitization whatever the dose } \\
\text { rate. }\end{array}$ & [44] \\
\hline $\begin{array}{l}\text { NSCLC cell lines } \\
(\mathrm{H} 460)\end{array}$ & $\begin{array}{l}\text { In vitro } \\
\text { In vivo }\end{array}$ & Veliparib $(5 \mu \mathrm{M})$ & 1,27 & Tumor growth delay increased of 6 days. & {$[106]$} \\
\hline $\begin{array}{l}\text { NSCLC cell lines } \\
\text { (Calu-6,A549) }\end{array}$ & $\begin{array}{l}\text { In vitro } \\
\text { In vivo }\end{array}$ & Olaparib $(1 \mu \mathrm{M})$ & 1,3 to 1,5 & Tumor growth delay increased of 10 Days & {$[108]$} \\
\hline $\begin{array}{l}\text { NSCLC cell lines } \\
\quad(\mathrm{H} 1299)\end{array}$ & In vitro & Veliparib $(2,5 \mu \mathrm{M})$ & 1,38 & Same results under hypoxia $(\mathrm{SER}=1,38)$ & [96] \\
\hline $\begin{array}{l}\text { NSCLC cell lines } \\
(\mathrm{H} 1299)\end{array}$ & In vitro & Olaparib $(1 \mu \mathrm{M})$ & 1,1 to 1,2 & Radiosensitization regardless p 53 status & [74] \\
\hline $\begin{array}{l}\text { NSCLC cell lines } \\
(\text { H1299, A549) }\end{array}$ & In vitro & Olaparib $(1 \mu \mathrm{M})$ & 1,3 to 2,2 & $\begin{array}{l}\text { No effect on A549. Hypothesis: In non-responders, } \\
\text { the induced DSBs are repaired exclusively by } \\
\text { NHEJIn responders, PARP1-EJ shares NHEJ in } \\
\text { repairing the DSBs induced after IR }\end{array}$ & {$[101]$} \\
\hline $\begin{array}{c}\text { NSCLC cell } \\
\text { lines (Calu- } \\
\text { 6,A549,H1299,H460) }\end{array}$ & In vitro & Niraparib $(1 \mu \mathrm{M})$ & $\begin{array}{c}\text { A 549: 1,32 H1299: } \\
\text { 1,34 H460: } 1,42 \text { Calu6: } \\
\text { 1,61 }\end{array}$ & $\begin{array}{l}\text { Radiosensitizing effect of niraparib is independent } \\
\text { of p53-status. }\end{array}$ & {$[100]$} \\
\hline $\begin{array}{l}\text { NSCLC cell lines } \\
(\mathrm{H} 460)\end{array}$ & In vitro & Olaparib $(1 \mu \mathrm{M})$ & Yes ( not communicated) & $\begin{array}{l}\text { p53 defective cells are more radiosensisitized by } \\
\text { olaparib. }\end{array}$ & {$[65]$} \\
\hline $\begin{array}{l}\text { NSCLC cell lines } \\
(\text { H460,A549,Calu-6) }\end{array}$ & In vivo & Niraparib $(1 \mu \mathrm{M})$ & Yes (In vivo) & $\begin{array}{l}\text { In vivo: } 1,4-2,2 \text { ( growth delay). 1or } 2 \text { Fraction/day } \\
\text { was found to be highly and similarly effective }\end{array}$ & {$[109]$} \\
\hline $\begin{array}{l}\text { NSCLC cell lines } \\
\text { (Calu-6,Calu-3) }\end{array}$ & $\begin{array}{l}\text { In vitro } \\
\text { In vivo }\end{array}$ & Olaparib $(5 \mu \mathrm{M})$ & Calu 3: 2,18 Calu 6: 1,95 & $\begin{array}{l}2,87 \text { under hypoxia } 2,44 \text { under hypoxia Tumor } \\
\text { growth delay increased only for Calu } 6 .\end{array}$ & {$[103]$} \\
\hline $\begin{array}{l}\text { NSCLC cell lines } \\
\text { (A549) }\end{array}$ & In vitro & $\begin{array}{c}\text { Olaparib }(5 \mu \mathrm{M})+ \\
\text { Protontherapy } \\
\end{array}$ & $\begin{array}{l}1,45 \text { at entrance region } \\
1,89 \text { in the bragg Peak }\end{array}$ & Increase of $\mathrm{G} 2 / \mathrm{M}$ arrest & [63] \\
\hline $\begin{array}{l}\text { NSCLC cell lines } \\
(\mathrm{H} 1299, \mathrm{H} 460)\end{array}$ & $\begin{array}{l}\text { In vitro } \\
\text { In vivo }\end{array}$ & $\begin{array}{l}\text { LT } 626(10 \mu \mathrm{M}) \\
\text { LT } 626(20 \mathrm{mg} / \mathrm{kg})\end{array}$ & Yes (not communicated) & $\begin{array}{l}\text { Survival was increased from } 13 \text { to } 20 \mathrm{~d} \text {. Tumor } \\
\text { burden was significantly lower. }\end{array}$ & [76] \\
\hline $\begin{array}{l}\text { SCLC cell lines } \\
(\mathrm{H} 146, \text { DMS153) }\end{array}$ & In vitro & Veliparib $(5 \mu \mathrm{M})$ & Yes (not communicated) & $\approx 30 \%$ decrease of survival fraction at $2 \mathrm{~Gy}$. & {$[105]$} \\
\hline
\end{tabular}

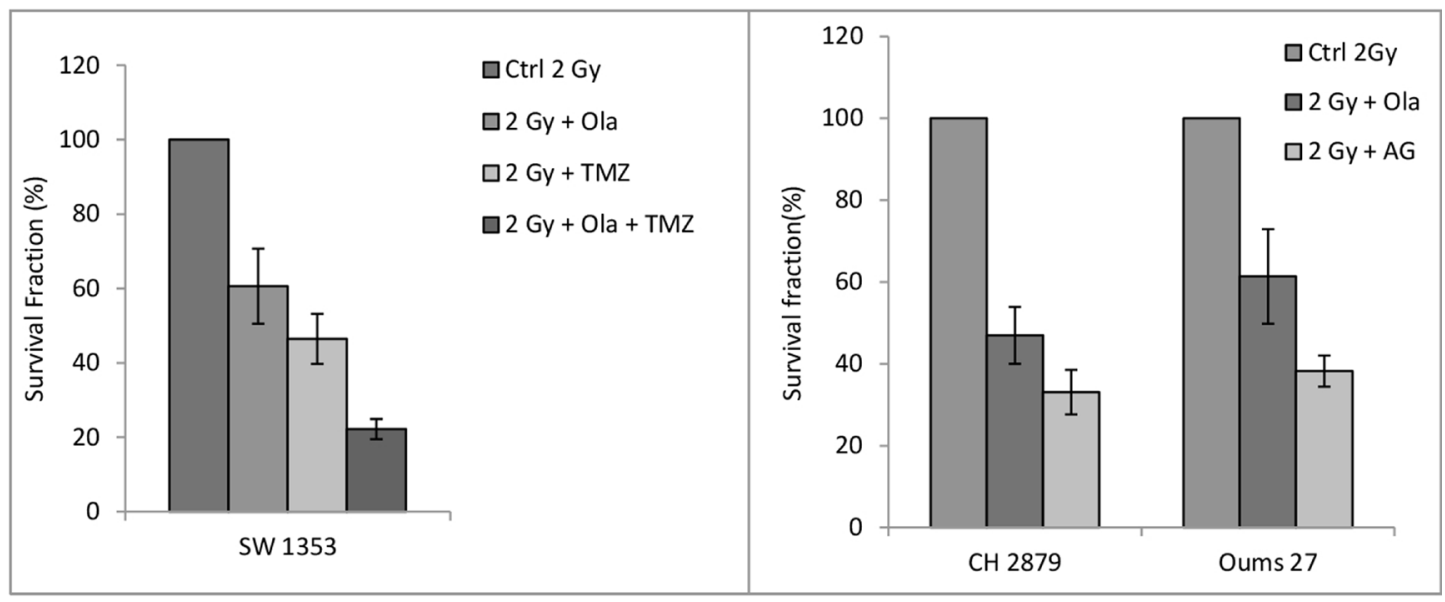

Figure 3: Clonogenic survival rate of chondrosarcoma cell after protontherapy sensitization with alkylant agents and PARPi. Chondrosarcoma cells were first cultured with Temozolomide and /or PARPi for 2 hours, then irradiated with proton beam at 2 Gy (62 MeV.u. ${ }^{-1}$, SOBP, $1,1 \mathrm{keV} \mathrm{u}^{-1}$ at LNS, Catania, Italy) and then left overnight at $37^{\circ} \mathrm{C}$. Cells were then seeded at low density for subsequent clonogenic assay, as previously described [116]. Left: survival fraction of SW1353 chondrosarcoma cells after 2 Gy proton alone, and with olaparib $(2 \mu \mathrm{M})$, temozolomide (Sigma-Aldrich ref T2577) $(20 \mu \mathrm{M})$ and olaparib with temozolomide $(2 \mu \mathrm{M}+20 \mu \mathrm{M}$ respectively). Right: survival fraction as a function of different chondrosarcoma cell lines. CH 2879 and Oums 27 are two other chondrosarcoma cell lines, showing that the variability of the response to the treatment is related to the cell line used. Cells were irradiated alone or with Olaparib (Focus biomolecules Ref 102154) at $2 \mu \mathrm{M}$, or AG (AG14361, Tebu-Bio, ref 27602-3) at 0.4 $\mu \mathrm{M}$. Each treatment is estimated as a percentage of the control sample, repeated 3 times. 
Table 7: Studies concerning PARPi radiosensitization for breast and gynecologic tumors

\begin{tabular}{|c|c|c|c|c|c|}
\hline \multicolumn{6}{|c|}{ Gynaecologic and breast cancer } \\
\hline Cell lines / tumor & Phase & PARP Inhibitor & ER & Comments & Ref \\
\hline $\begin{array}{l}\text { Breast Cancer cell line } \\
\text { (MCF7) }\end{array}$ & $\begin{array}{l}\text { In vitro } \\
\text { In vivo }\end{array}$ & Veliparib (10 uM, 0,5 mg Bid) & Yes ( Not communicated) & $\begin{array}{c}\text { Colony formation } \\
\text { following } 2 \text { Gy decreased } \\
\text { from } 29.7 \text { to } 11.3 \% \\
\text { with veliparib. The } \\
\text { antiproliferative effects } \\
\text { of } 3 \text { Gy enhance from } 41 \\
\text { to } 27 \%\end{array}$ & [111] \\
\hline $\begin{array}{l}\text { Breast Cancer cell line } \\
\text { (MDA-MB-231) }\end{array}$ & In vivo & Niraparib ( 25 to $50 \mathrm{mg} / \mathrm{kg}$ ) & Yes (In vivo) & $\begin{array}{l}\text { In vivo: increase growth } \\
\text { delay } x 1,9\end{array}$ & [109] \\
\hline $\begin{array}{c}\text { Breast Cancer cell lines } \\
\text { (MDA-MB-231, MDA- } \\
\text { MB-436) }\end{array}$ & $\begin{array}{l}\text { In vitro } \\
\text { In vivo }\end{array}$ & Niraparib $(1 \mu \mathrm{M})$ & 1,25 to 1,36 & $\begin{array}{l}\text { Normal breast cell line } \\
\text { MCF 10A only slightly } \\
\text { radiosensitized. }\end{array}$ & {$[100]$} \\
\hline $\begin{array}{c}\text { Breast Cancer cell line } \\
\text { (ZR75-1, MDA-MB-231, } \\
\text { MDA-MB-468, MDA- } \\
\text { MB-453,HCC 1954, HCC } \\
\text { 1937) }\end{array}$ & $\begin{array}{l}\text { In vitro } \\
\text { In vivo }\end{array}$ & $\begin{array}{c}\text { Veliparib }(2,5 \mathrm{uM}) \text { Veliparib } 100 \\
\mathrm{mg} / \mathrm{Kg}\end{array}$ & 1,22 to 2,31 & $\begin{array}{l}\text { In vivo: Tumor volume } \\
\quad \text { doubling time } \approx \mathrm{x} 2\end{array}$ & {$[110]$} \\
\hline $\begin{array}{l}\text { Triple negative breast } \\
\text { cancer }\end{array}$ & Phase I & Veliparib +50 Gy & Not applicable & 30 patients. Safety Data & {$[112]$} \\
\hline $\begin{array}{l}\text { Cervix carcinoma cell } \\
\text { line (Hela) }\end{array}$ & In vitro & Olaparib $(1 \mu \mathrm{M})$ & 1,3 to 2,2 & $\begin{array}{c}\text { PARP inhibition } \\
\text { significantly increased } \\
\text { the number ofpersistent } \\
\text { gH2AX foci at } 24 \mathrm{~h} \text { but } \\
\text { not at } 1 \mathrm{~h}\end{array}$ & {$[101]$} \\
\hline $\begin{array}{l}\text { Cervix carcinoma cell line } \\
(\mathrm{HX} 155,156,160)\end{array}$ & In vivo & 3-Amino-benzamide (8 mM) & 1,02 to 1,37 & None & [113] \\
\hline $\begin{array}{l}\text { Cervix carcinoma cell } \\
\text { line (Hela) }\end{array}$ & In vitro & $\begin{array}{l}\text { 4-amino-1,8-naphthalimide } \\
\qquad(30 \mu \mathrm{M})\end{array}$ & No & $\begin{array}{l}\text { No significant increase of } \\
\text { radiosensitivity }\end{array}$ & [15] \\
\hline $\begin{array}{c}\text { Cervix carcinoma cell line } \\
\text { (HX 156c) }\end{array}$ & In vitro & 3-Amino-benzamide (8 mM) & 1,16 to 1,18 & $\begin{array}{c}\text { Absence of } \\
\text { radiosensitization } \\
\text { whatever the dose rate. }\end{array}$ & [44] \\
\hline
\end{tabular}

lines are very limited $[63,117]$ and there are too few of phase I studies to bring some conclusions. Nevertheless as single agent, in phase III study, Olaparib increased the risk of myelodysplasia or acute myeloid leukemia [118]. These secondary effects could be enhanced if large field spine or pelvic radiotherapy was associated. Waiting for more data, and to avoid unexpected late toxicity, we should pay attention to the use of hadrontherapy, stereotactic radiotherapy or radionuclides in combination with PARPi. These techniques offer better ballistic and superior biological efficiency, bringing a promise of improvement of the therapeutic ratio [119].

If BRCA and PTEN mutations are actually known for being predictive of high efficiency of PARP inhibitor [120], accurate biomarkers for response and resistance to PARPi are still needed. Intratumoral levels and activity of the PARP does not correlate with clinical responses in patients and shouldn't be considered as predictive of response [121]. On the contrary, homologous recombination assay, targeted multiplex sequencing, mutational signatures and alterations in genome structure, functional assay, are potential solutions to identify biomarkers [122]. For example Olaparib as single agent for patients suffering from prostate cancer with genetic aberrations in DNA-repair genes has showed significantly higher efficacy with $88 \%$ overall response rate. In this study, 12 genes were evaluated: BRCA1, BRCA2, ATM, FANCA, CHK2, PALB2, HDAC2, RAD 51, MLH3, ERCC3, MRE 11 and NBN [91]. Future phase I or II studies should systematically include tumoral DNA Repair capacity status, in order to better select patient who will benefit from the treatment.

Finally we come to the conclusion that the permanent development of new targeted therapies makes radiotherapist hope for new interesting pair with radiotherapy. Combinations of PARPi with radiotherapy seem very promising but clinical data are still lacking. Radiotherapists and searchers should pay attention to include ancillary studies, in addition to clinic ones, in order to develop biomarkers. The next ten years will be crucial for judging the real potential of PARPi as radiosensistizer.

\section{CONFLICTS OF INTEREST}

None. 


\section{REFERENCES}

1. Farmer H, McCabe N, Lord CJ, Tutt ANJ, Johnson DA, Richardson TB, Santarosa M, Dillon KJ, Hickson I, Knights C, Martin NMB, Jackson SP, Smith GCM, et al. Targeting the DNA repair defect in BRCA mutant cells as a therapeutic strategy. Nature. 2005; 434:917-21. https://doi. org/10.1038/nature03445.

2. Bryant HE, Schultz N, Thomas HD, Parker KM, Flower D, Lopez E, Kyle S, Meuth M, Curtin NJ, Helleday T. Specific killing of BRCA2-deficient tumours with inhibitors of poly(ADP-ribose) polymerase. Nature. 2005; 434:913-7. https://doi.org/10.1038/nature03443.

3. Brown JM, Carlson DJ, Brenner DJ. The tumor radiobiology of SRS and SBRT: are more than the 5 Rs involved? Int J Radiat Oncol Biol Phys. 2014; 88:254-62. https://doi. org/10.1016/j.ijrobp.2013.07.022.

4. Mansour WY, Rhein T, Dahm-Daphi J. The alternative end-joining pathway for repair of DNA double-strand breaks requires PARP1 but is not dependent upon microhomologies. Nucleic Acids Res. 2010; 38:6065-77. https://doi.org/10.1093/nar/gkq387.

5. Schultz N, Lopez E, Saleh-Gohari N, Helleday T. Poly(ADP-ribose) polymerase (PARP-1) has a controlling role in homologous recombination. Nucleic Acids Res. 2003; 31:4959-64. https://doi.org/10.1093/nar/gkg703.

6. Cheng Q, Barboule N, Frit P, Gomez D, Bombarde O, Couderc B, Ren GS, Salles B, Calsou P. Ku counteracts mobilization of PARP1 and MRN in chromatin damaged with DNA double-strand breaks. Nucleic Acids Res. 2011; 39:9605-19. https://doi.org/10.1093/nar/gkr656.

7. Gradwohl G, Ménissier de Murcia JM, Molinete M, Simonin F, Koken M, Hoeijmakers JH, de Murcia G. The second zinc-finger domain of poly(ADP-ribose) polymerase determines specificity for single-stranded breaks in DNA. Proc Natl Acad Sci. 1990; 87:2990-4. https://doi. org/10.1073/pnas.87.8.2990.

8. Ikejima M, Noguchi S, Yamashita R, Ogura T, Sugimura T, Gill DM, Miwa M. The zinc fingers of human poly(ADPribose) polymerase are differentially required for the recognition of DNA breaks and nicks and the consequent enzyme activation. Other structures recognize intact DNA. J Biol Chem. 1990; 265:21907-13.

9. Li M, Yu X. The Role of Poly(ADP-ribosyl)ation in DNA Damage Response and Cancer Chemotherapy. Oncogene. 2015; 34:3349-56. https://doi.org/10.1038/onc.2014.295.

10. Saintigny Y, Delacôte F, Varès G, Petitot F, Lambert S, Averbeck D, Lopez BS. Characterization of homologous recombination induced by replication inhibition in mammalian cells. EMBO J. 2001; 20:3861-70. https://doi. org/10.1093/emboj/20.14.3861.

11. Ström CE, Johansson F, Uhlén M, Szigyarto CA, Erixon K, Helleday T. Poly (ADP-ribose) polymerase (PARP) is not involved in base excision repair but PARP inhibition traps a single-strand intermediate. Nucleic
Acids Res. 2011; 39:3166-75. https://doi.org/10.1093/nar/ gkq1241.

12. Cerrato A, Morra F, Celetti A. Use of poly ADP-ribose polymerase [PARP] inhibitors in cancer cells bearing DDR defects: the rationale for their inclusion in the clinic. J Exp Clin Cancer Res. 2016; 35:179. https://doi.org/10.1186/s13046-0160456-2.

13. Bryant HE, Petermann E, Schultz N, Jemth AS, Loseva O, Issaeva N, Johansson F, Fernandez S, McGlynn P, Helleday T. PARP is activated at stalled forks to mediate Mre11-dependent replication restart and recombination. EMBO J. 2009; 28:2601-15. https://doi.org/10.1038/ emboj.2009.206.

14. Grabarz A, Barascu A, Guirouilh-Barbat J, Lopez BS. Initiation of DNA double strand break repair: signaling and single-stranded resection dictate the choice between homologous recombination, non-homologous end-joining and alternative end-joining. Am J Cancer Res. 2012; 2:249-68.

15. Noël G, Godon C, Fernet M, Giocanti N, Mégnin-Chanet F, Favaudon V. Radiosensitization by the poly(ADP-ribose) polymerase inhibitor 4-amino-1,8-naphthalimide is specific of the $\mathrm{S}$ phase of the cell cycle and involves arrest of DNA synthesis. Mol Cancer Ther. 2006; 5:564-74. https://doi. org/10.1158/1535-7163.MCT-05-0418.

16. Dungey FA, Löser DA, Chalmers AJ. Replication-dependent radiosensitization of human glioma cells by inhibition of poly(ADP-Ribose) polymerase: mechanisms and therapeutic potential. Int J Radiat Oncol Biol Phys. 2008; 72:1188-97. https://doi.org/10.1016/j.ijrobp.2008.07.031.

17. Gottschalk AJ, Timinszky G, Kong SE, Jin J, Cai Y, Swanson SK, Washburn MP, Florens L, Ladurner AG, Conaway JW, Conaway RC. Poly(ADP-ribosyl)ation directs recruitment and activation of an ATP-dependent chromatin remodeler. Proc Natl Acad Sci USA. 2009; 106:13770-4. https://doi.org/10.1073/pnas.0906920106.

18. Ahel D, Horejsí Z, Wiechens N, Polo SE, Garcia-Wilson E, Ahel I, Flynn H, Skehel M, West SC, Jackson SP, OwenHughes T, Boulton SJ. Poly(ADP-ribose)-dependent regulation of DNA repair by the chromatin remodeling enzyme ALC1. Science. 2009; 325:1240-3. https://doi. org/10.1126/science.1177321.

19. Gorbalenya AE, Koonin EV, Donchenko AP, Blinov VM. Two related superfamilies of putative helicases involved in replication, recombination, repair and expression of DNA and RNA genomes. Nucleic Acids Res. 1989; 17:4713-30.

20. Ali M, Telfer BA, McCrudden C, O'Rourke M, Thomas HD, Kamjoo M, Kyle S, Robson T, Shaw C, Hirst DG, Curtin NJ, Williams KJ. Vasoactivity of AG014699, a clinically active small molecule inhibitor of poly(ADP-ribose) polymerase: a contributory factor to chemopotentiation in vivo? Clin Cancer Res. 2009; 15:6106-12. https://doi. org/10.1158/1078-0432.CCR-09-0398.

21. Brown JM, Wilson WR. Exploiting tumour hypoxia in cancer treatment. Nat Rev Cancer. 2004; 4:437-47. https:// doi.org/10.1038/nrc1367. 
22. Hong BJ, Kim J, Jeong H, Bok S, Kim YE, Ahn GO. Tumor hypoxia and reoxygenation: the yin and yang for radiotherapy. Radiat Oncol J. 2016; 34:239-49. https://doi. org/10.3857/roj.2016.02012.

23. Brown JM, Wilson WR. Exploiting tumour hypoxia in cancer treatment. Nat Rev Cancer. 2004; 4:437-47. https:// doi.org/10.1038/nrc1367.

24. Loeb LA. Human Cancers Express a Mutator Phenotype: Hypothesis, Origin, and Consequences. Cancer Res. 2016; 76:2057-9. https://doi.org/10.1158/0008-5472.CAN-160794.

25. Bristow RG, Hill RP. Hypoxia and metabolism. Hypoxia, DNA repair and genetic instability. Nat Rev Cancer. 2008; 8:180-92. https://doi.org/10.1038/nrc2344.

26. Chan N, Pires IM, Bencokova Z, Coackley C, Luoto KR, Bhogal N, Lakshman M, Gottipati P, Oliver FJ, Helleday T, Hammond EM, Bristow RG. Contextual Synthetic Lethality of Cancer Cell Kill Based on the Tumor Microenvironment. Cancer Res. 2010; 70:8045-54. https://doi.org/10.1158/00085472.CAN-10-2352.

27. Pawlik TM, Keyomarsi K. Role of cell cycle in mediating sensitivity to radiotherapy. Int J Radiat Oncol Biol Phys. 2004; 59:928-42. https://doi.org/10.1016/j.ijrobp.2004.03.005.

28. Ledermann J, Harter P, Gourley C, Friedlander M, Vergote I, Rustin G, Scott CL, Meier W, Shapira-Frommer R, Safra T, Matei D, Fielding A, Spencer S, et al. Olaparib maintenance therapy in patients with platinum-sensitive relapsed serous ovarian cancer: a preplanned retrospective analysis of outcomes by BRCA status in a randomised phase 2 trial. Lancet Oncol. 2014; 15:852-61. https://doi.org/10.1016/ S1470-2045(14)70228-1.

29. Drew Y, Ledermann J, Hall G, Rea D, Glasspool R, Highley M, Jayson G, Sludden J, Murray J, Jamieson D, Halford S, Acton G, Backholer Z, et al. Phase 2 multicentre trial investigating intermittent and continuous dosing schedules of the poly(ADP-ribose) polymerase inhibitor rucaparib in germline BRCA mutation carriers with advanced ovarian and breast cancer. Br J Cancer. 2016; 114:723-30. https://doi.org/10.1038/bjc.2016.41.

30. Mirza MR, Monk BJ, Herrstedt J, Oza AM, Mahner S, Redondo A, Fabbro M, Ledermann JA, Lorusso D, Vergote I, Ben-Baruch NE, Marth C, Mądry R, et al. Niraparib Maintenance Therapy in Platinum-Sensitive, Recurrent Ovarian Cancer. N Engl J Med. 2016; 375:2154-64. https:// doi.org/10.1056/NEJMoa1611310.

31. Domchek SM, Aghajanian C, Shapira-Frommer R, Schmutzler RK, Audeh MW, Friedlander M, Balmaña J, Mitchell G, Fried G, Stemmer SM, Hubert A, Rosengarten O, Loman N, et al. Efficacy and safety of olaparib monotherapy in germline BRCA1/2 mutation carriers with advanced ovarian cancer and three or more lines of prior therapy. Gynecol Oncol. 2016; 140:199-203. https://doi.org/10.1016/j. ygyno.2015.12.020.

32. Helleday T. The underlying mechanism for the PARP and BRCA synthetic lethality: clearing up the misunderstandings. Mol Oncol. 2011; 5:387-93. https://doi. org/10.1016/j.molonc.2011.07.001.

33. Kedar PS, Stefanick DF, Horton JK, Wilson SH. Increased PARP-1 association with DNA in alkylation damaged, PARP-inhibited mouse fibroblasts. Mol Cancer Res. 2012; 10:360-8. https://doi.org/10.1158/1541-7786. MCR-11-0477.

34. Moher D, Liberati A, Tetzlaff J, Altman DG, PRISMA Group. Preferred reporting items for systematic reviews and metaanalyses: the PRISMA statement. J Clin Epidemiol. 2009; 62:1006-12. https://doi.org/10.1016/j.jclinepi.2009.06.005.

35. Chalmers A, Johnston $\mathrm{P}$, Woodcock $\mathrm{M}$, Joiner $\mathrm{M}$, Marples B. PARP-1, PARP-2, and the cellular response to low doses of ionizing radiation. Int J Radiat Oncol Biol Phys. 2004; 58:410-9.

36. Russo AL, Kwon HC, Burgan WE, Carter D, Beam K, Weizheng X, Zhang J, Slusher BS, Chakravarti A, Tofilon PJ, Camphausen K. In vitro and In vivo Radiosensitization of Glioblastoma Cells by the Poly (ADP-Ribose) Polymerase Inhibitor E7016. Clin Cancer Res. 2009; 15:607-12. https:// doi.org/10.1158/1078-0432.CCR-08-2079.

37. van Vuurden DG, Hulleman E, Meijer OL, Wedekind LE, Kool M, Witt H, Vandertop PW, Würdinger T, Noske DP, Kaspers GJ, Cloos J. PARP inhibition sensitizes childhood high grade glioma, medulloblastoma and ependymoma to radiation. Oncotarget. 2011; 2:984-96. https://doi. org/10.18632/oncotarget.362.

38. Barazzuol L, Jena R, Burnet NG, Meira LB, Jeynes JCG, Kirkby KJ, Kirkby NF. Evaluation of poly (ADP-ribose) polymerase inhibitor ABT-888 combined with radiotherapy and temozolomide in glioblastoma. Radiat Oncol. 2013; 8:65. https://doi.org/10.1186/1748-717X-8-65.

39. Nile DL, Rae C, Hyndman IJ, Gaze MN, Mairs RJ. An evaluation in vitro of PARP-1 inhibitors, rucaparib and olaparib, as radiosensitisers for the treatment of neuroblastoma. BMC Cancer. 2016; 16:621. https://doi.org/10.1186/s12885-016-2656-8.

40. Jue TR, Nozue K, Lester AJ, Joshi S, Schroder LBW, Whittaker SP, Nixdorf S, Rapkins RW, Khasraw M, McDonald KL. Veliparib in combination with radiotherapy for the treatment of MGMT unmethylated glioblastoma. J Transl Med. 2017; 15:61. https://doi.org/10.1186/s12967017-1164-1.

41. Ahmed SU, Carruthers R, Gilmour L, Yildirim S, Watts C, Chalmers AJ. Selective Inhibition of Parallel DNA Damage Response Pathways Optimizes Radiosensitization of Glioblastoma Stem-like Cells. Cancer Res. 2015; 75:4416-28. https://doi.org/10.1158/0008-5472.CAN-14-3790.

42. Chornenkyy $\mathrm{Y}$, Agnihotri S, Yu M, Buczkowicz P, Rakopoulos P, Golbourn B, Garzia L, Siddaway R, Leung S, Rutka JT, Taylor MD, Dirks PB, Hawkins C. Poly-ADPRibose Polymerase as a Therapeutic Target in Pediatric Diffuse Intrinsic Pontine Glioma and Pediatric High-Grade Astrocytoma. Mol Cancer Ther. 2015; 14:2560-8. https:// doi.org/10.1158/1535-7163.MCT-15-0282.

43. Mueller S, Bhargava S, Molinaro AM, Yang X, Kolkowitz I, Olow A, Wehmeijer N, Orbach S, Chen J, 
Matthay KK, Haas-Kogan DA. Poly (ADP-Ribose) polymerase inhibitor MK-4827 together with radiation as a novel therapy for metastatic neuroblastoma. Anticancer Res. 2013; 33:755-62.

44. Kelland LR, Burgess L, Steel GG. Differential radiosensitization by the poly(ADP-ribose) transferase inhibitor 3-aminobenzamide in human tumor cells of varying radiosensitivity. Int J Radiat Oncol Biol Phys. 1988; 14:1239-46.

45. Kleinberg L, Supko JG, Mikkelsen T, Blakeley JO, Stevens G, Ye X, Desideri S, Ryu S, Desai B, Giranda VL, Grossman SA. Phase I adult brain tumor consortium (ABTC) trial of ABT-888 (veliparib), temozolomide (TMZ), and radiotherapy (RT) for newly diagnosed glioblastoma multiforme (GBM) including pharmacokinetic (PK) data. J Clin Oncol. 2013 [cited $2017 \mathrm{Feb} 27$ ]; 31. Available from http://meetinglibrary. asco.org/content/114064-132

46. Mehta MP, Curran WJ, Wang D, Wang F, Kleinberg L, Brade AM, Mostafa N, Zhou X, Qian J, Leahy T, Desai B, Giranda VL. Phase I safety and pharmacokinetic (PK) study of veliparib in combination with whole brain radiation therapy (WBRT) in patients (pts) with brain metastases. J Clin Oncol. 2012 [cited 2017 Feb 27]; 30. Available from http://meetinglibrary.asco.org/content/96956-114

47. Baxter P, Su J, Li X, Thomas AO, Billups C, Thompson P, Poussaint T, McKeegan E, Wan X, Ansell P, Giranda V, Paulino A, Kilburn L, et al. Ept-15a phase1/2 clinical trial of veliparib (abt-888) and radiation followed by maintenance therapy with veliparib and temozolomide (tmz) in patients with newly diagnosed diffuse intrinsic pontine glioma (dipg): a pediatric brain tumor consortium interim report of phase ii study. Neuro-Oncol. 2016; 18:iii27-iii27. https:// doi.org/10.1093/neuonc/now069.14.

48. Chabot P, Hsia TC, Ryu JS, Gorbunova V, Belda-Iniesta C, Ball D, Kio E, Mehta M, Papp K, Qin Q, Qian J, Holen KD, Giranda V, et al. Veliparib in combination with whole-brain radiation therapy for patients with brain metastases from non-small cell lung cancer: results of a randomized, global, placebo-controlled study. J Neurooncol. 2017; 131:105-15. https://doi.org/10.1007/s11060-016-2275-x.

49. Galia A, Calogero AE, Condorelli R, Fraggetta F, La Corte A, Ridolfo F, Bosco P, Castiglione R, Salemi M. PARP-1 protein expression in glioblastoma multiforme. Eur J Histochem. 2012; 56:e9. https://doi.org/10.4081/ejh.2012.e9.

50. Bao S, Wu Q, McLendon RE, Hao Y, Shi Q, Hjelmeland AB, Dewhirst MW, Bigner DD, Rich JN. Glioma stem cells promote radioresistance by preferential activation of the DNA damage response. Nature. 2006; 444:756-60. https:// doi.org/10.1038/nature05236.

51. Venere M, Hamerlik P, Wu Q, Rasmussen RD, Song LA, Vasanji A, Tenley N, Flavahan WA, Hjelmeland AB, Bartek J, Rich JN. Therapeutic targeting of constitutive PARP activation compromises stem cell phenotype and survival of glioblastoma-initiating cells. Cell Death Differ. 2014; 21:258-69. https://doi.org/10.1038/cdd.2013.136.
52. Stupp R, Mason WP, van den Bent MJ, Weller M, Fisher B, Taphoorn MJB, Belanger K, Brandes AA, Marosi C, Bogdahn U, Curschmann J, Janzer RC, Ludwin SK, et al. Radiotherapy plus concomitant and adjuvant temozolomide for glioblastoma. N Engl J Med. 2005; 352:987-96. https:// doi.org/10.1056/NEJMoa043330.

53. Miknyoczki S, Chang H, Grobelny J, Pritchard S, Worrell C, McGann N, Ator M, Husten J, Deibold J, Hudkins R, Zulli A, Parchment R, Ruggeri B. The selective poly(ADP-ribose) polymerase-1(2) inhibitor, CEP-8983, increases the sensitivity of chemoresistant tumor cells to temozolomide and irinotecan but does not potentiate myelotoxicity. Mol Cancer Ther. 2007; 6:2290-302. https://doi.org/10.1158/1535-7163.MCT-07-0062.

54. Miknyoczki SJ, Jones-Bolin S, Pritchard S, Hunter K, Zhao H, Wan W, Ator M, Bihovsky R, Hudkins R, Chatterjee S, Klein-Szanto A, Dionne C, Ruggeri B. Chemopotentiation of temozolomide, irinotecan, and cisplatin activity by CEP-6800, a poly(ADP-ribose) polymerase inhibitor. Mol Cancer Ther. 2003; 2:371-82.

55. Tentori L, Ricci-Vitiani L, Muzi A, Ciccarone F, Pelacchi F, Calabrese R, Runci D, Pallini R, Caiafa P, Graziani G. Pharmacological inhibition of poly(ADP-ribose) polymerase-1 modulates resistance of human glioblastoma stem cells to temozolomide. BMC Cancer. 2014; 14:151. https://doi.org/10.1186/1471-2407-14-151.

56. Balvers RK, Lamfers MLM, Kloezeman JJ, Kleijn A, Berghauser Pont LME, Dirven CMF, Leenstra S. ABT-888 enhances cytotoxic effects of temozolomide independent of MGMT status in serum free cultured glioma cells. J Transl Med. 2015; 13:74. https://doi.org/10.1186/s12967-015-0427-y.

57. Gupta SK, Mladek AC, Carlson BL, Boakye-Agyeman F, Bakken KK, Kizilbash SH, Schroeder MA, Reid J, Sarkaria JN. Discordant in vitro and in vivo chemopotentiating effects of the PARP inhibitor veliparib in temozolomidesensitive versus -resistant glioblastoma multiforme xenografts. Clin Cancer Res. 2014; 20:3730-41. https://doi. org/10.1158/1078-0432.CCR-13-3446.

58. Gupta SK, Kizilbash SH, Carlson BL, Mladek AC, BoakyeAgyeman F, Bakken KK, Pokorny JL, Schroeder MA, Decker PA, Cen L, Eckel-Passow JE, Sarkar G, Ballman KV, et al. Delineation of MGMT Hypermethylation as a Biomarker for Veliparib-Mediated TemozolomideSensitizing Therapy of Glioblastoma. J Natl Cancer Inst. 2016; 108. https://doi.org/10.1093/jnci/djv369.

59. McEllin B, Camacho CV, Mukherjee B, Hahm B, Tomimatsu N, Bachoo RM, Burma S. PTEN Loss Compromises Homologous Recombination Repair in Astrocytes: Implications for Glioblastoma Therapy with Temozolomide or Poly(ADP-Ribose) Polymerase Inhibitors. Cancer Res. 2010; 70:5457-64. https://doi. org/10.1158/0008-5472.CAN-09-4295.

60. Donawho CK, Luo Y, Luo Y, Penning TD, Bauch JL, Bouska JJ, Bontcheva-Diaz VD, Cox BF, DeWeese TL, Dillehay LE, Ferguson DC, Ghoreishi-Haack NS, Grimm DR, et al. ABT-888, an orally active poly(ADP-ribose) polymerase 
inhibitor that potentiates DNA-damaging agents in preclinical tumor models. Clin Cancer Res. 2007; 13:2728-37. https:// doi.org/10.1158/1078-0432.CCR-06-3039.

61. Murphy KM, Brune KA, Griffin C, Sollenberger JE, Petersen GM, Bansal R, Hruban RH, Kern SE. Evaluation of candidate genes MAP2K4, MADH4, ACVR1B, and BRCA2 in familial pancreatic cancer: deleterious BRCA2 mutations in 17\%. Cancer Res. 2002; 62:3789-93.

62. Porcelli L, Quatrale AE, Mantuano P, Leo MG, Silvestris N, Rolland JF, Carioggia E, Lioce M, Paradiso A, Azzariti A. Optimize radiochemotherapy in pancreatic cancer: PARP inhibitors a new therapeutic opportunity. Mol Oncol. 2013; 7:308-22. https://doi.org/10.1016/j.molonc.2012.10.002.

63. Hirai T, Saito S, Fujimori H, Matsushita K, Nishio T, Okayasu R, Masutani M. Radiosensitization by PARP inhibition to proton beam irradiation in cancer cells. Biochem Biophys Res Commun. 2016; 478:234-40. https:// doi.org/10.1016/j.bbrc.2016.07.062.

64. Karnak D, Engelke CG, Parsels LA, Kausar T, Wei D, Robertson JR, Marsh KB, Davis MA, Zhao L, Maybaum J, Lawrence TS, Morgan MA. Combined inhibition of Wee1 and PARP1/2 for radiosensitization in pancreatic cancer. Clin Cancer Res. 2014; 20:5085-96. https://doi.org/10.1158/10780432.CCR-14-1038.

65. Vance S, Liu E, Zhao L, Parsels JD, Parsels LA, Brown JL, Maybaum J, Lawrence TS, Morgan MA. Selective radiosensitization of p53 mutant pancreatic cancer cells by combined inhibition of Chk1 and PARP1. Cell Cycle. 2011; 10:4321-9. https://doi.org/10.4161/cc.10.24.18661.

66. Hirai T, Shirai H, Fujimori H, Okayasu R, Sasai K, Masutani M. Radiosensitization effect of poly(ADP-ribose) polymerase inhibition in cells exposed to low and high liner energy transfer radiation. Cancer Sci. 2012; 103:1045-50. https://doi.org/10.1111/j.1349-7006.2012.02268.x.

67. ESTRO 36 Abstract Book. [cited 2017 May 13]. Available 2017 May 13, from https://cld.bz/bookdata/19T1ww/basichtml/page-17.html

68. Lohse I, Kumareswaran R, Cao P, Pitcher B, Gallinger S, Bristow RG, Hedley DW. Effects of Combined Treatment with Ionizing Radiation and the PARP Inhibitor Olaparib in BRCA Mutant and Wild Type Patient-Derived Pancreatic Cancer Xenografts. PLoS One. 2016; 11:e0167272. https:// doi.org/10.1371/journal.pone.0167272.

69. Tuli R, Nissen NN, Annamalai A, Hoffman DMJ, Bryant M, Tighiouart M, Rogatko A, Rokhsar S, Scher KS, Jamil L, Lo $\mathrm{S}$, Hendifar AE. Phase I study of veliparib with gemcitabine and radiation therapy in patients with borderline resectable and locally advanced unresectable pancreatic cancer. J Clin Oncol. 2016; 34:TPS487-TPS487. https://doi.org/10.1200/ jco.2016.34.4_suppl.tps487.

70. Kindler HL, Locker GY, Mann H, Golan T. POLO: A randomized phase III trial of olaparib tablets in patients with metastatic pancreatic cancer ( $\mathrm{mPC}$ ) and a germline BRCA1/2mutation (gBRCAm) who have not progressed following first-line chemotherapy. J Clin Oncol. 2015 [cited
2017 Mar 16]; 33. Available from http://meetinglibrary. asco.org/content/147076-156

71. Shelton JW, Waxweiler TV, Landry J, Gao H, Xu Y, Wang L, El-Rayes B, Shu H-KG. In vitro and in vivo enhancement of chemoradiation using the oral PARP inhibitor ABT-888 in colorectal cancer cells. Int J Radiat Oncol Biol Phys. 2013; 86:469-76. https://doi.org/10.1016/j.ijrobp.2013.02.015.

72. Michael M, Mulcahy MF, Deming DA, Vaghefi $H$, Jameson GS, DeLuca A, Xiong H, Munasinghe W, Dudley MW, Komarnitsky P, Holen KD, Czito BG. Safety and tolerability of veliparib combined with capecitabine plus radiotherapy in patients with locally advanced rectal cancer (LARC): Final results of a phase Ib study. J Clin Oncol. 2015 [cited 2017 Mar 17]; 33. Available from http:// meetinglibrary.asco.org/content/144666-156

73. Calabrese CR, Almassy R, Barton S, Batey MA, Calvert AH, Canan-Koch S, Durkacz BW, Hostomsky Z, Kumpf RA, Kyle S, Li J, Maegley K, Newell DR, et al. Anticancer Chemosensitization and Radiosensitization by the Novel Poly(ADP-ribose) Polymerase-1 Inhibitor AG14361. J Natl Cancer Inst. 2004; 96:56-67. https://doi.org/10.1093/jnci/ djh005.

74. Miura K, Sakata K, Someya M, Matsumoto Y, Matsumoto H, Takahashi A, Hareyama M. The combination of olaparib and camptothecin for effective radiosensitization. Radiat Oncol. 2012; 7:62. https://doi.org/10.1186/1748-717X-7-62.

75. Alotaibi M, Sharma K, Saleh T, Povirk LF, Hendrickson EA, Gewirtz DA. Radiosensitization by PARP Inhibition in DNA Repair Proficient and Deficient Tumor Cells: Proliferative Recovery in Senescent Cells. Radiat Res. 2016; 185:22945. https://doi.org/10.1667/RR14202.1.

76. Hastak K, Bhutra S, Parry R, Ford JM. Poly (ADP-ribose) polymerase inhibitor, an effective radiosensitizer in lung and pancreatic cancers. Oncotarget. 2017; 8:26344-55. https://doi.org/10.18632/oncotarget.15464.

77. Guillot C, Favaudon V, Herceg Z, Sagne C, Sauvaigo S, Merle P, Hall J, Chemin I. PARP inhibition and the radiosensitizing effects of the PARP inhibitor ABT-888 in in vitro hepatocellular carcinoma models. BMC Cancer. 2014; 14:603. https://doi.org/10.1186/1471-2407-14-603.

78. Czito BG, Deming DA, Jameson GS, Mulcahy MF, Vaghefi H, Dudley MW, Holen KD, DeLuca A, Mittapalli RK, Munasinghe W, He L, Zalcberg JR, Ngan SY, et al. Safety and tolerability of veliparib combined with capecitabine plus radiotherapy in patients with locally advanced rectal cancer: a phase 1b study. Lancet Gastroenterol Hepatol. 2017; 2:418-26. https://doi.org/10.1016/S2468-1253(17)30012-2.

79. Reiss KA, Herman JM, Armstrong D, Zahurak M, Fyles A, Brade A, Milosevic M, Dawson LA, Scardina A, Fischer P, Hacker-Prietz A, Kinders RJ, Wang L, et al. A final report of a phase I study of veliparib (ABT-888) in combination with low-dose fractionated whole abdominal radiation therapy (LDFWAR) in patients with advanced solid malignancies and peritoneal carcinomatosis with a dose escalation in ovarian and fallopian tube cancers. Gynecol Oncol. 2017; 144:486-90. https://doi.org/10.1016/j.ygyno.2017.01.016. 
80. Strom TJ, Naghavi AO, Trotti AM, Russell J, Kish JA, McCaffrey J, Otto KJ, Harrison LB, Caudell JJ. Increased acute mortality with chemoradiotherapy for locally advanced head and neck cancer in patients $\geq 70$ years. J Geriatr Oncol. 2017; 8:50-5. https://doi.org/10.1016/j. jgo.2016.09.003.

81. Güster JD, Weissleder SV, Busch C-J, Kriegs M, Petersen C, Knecht R, Dikomey E, Rieckmann T. The inhibition of PARP but not EGFR results in the radiosensitization of HPV/p16-positive HNSCC cell lines. Radiother Oncol. 2014; 113:345-51. https://doi.org/10.1016/j. radonc.2014.10.011.

82. Nickson CM, Moori P, Carter RJ, Rubbi CP, Parsons JL. Misregulation of DNA damage repair pathways in HPVpositive head and neck squamous cell carcinoma contributes to cellular radiosensitivity. Oncotarget. 2017; 8:29963-75. https://doi.org/10.18632/oncotarget.16265.

83. Wurster S, Hennes F, Parplys AC, Seelbach JI, Mansour WY, Zielinski A, Petersen C, Clauditz TS, Münscher A, Friedl AA, Borgmann K. PARP1 inhibition radiosensitizes HNSCC cells deficient in homologous recombination by disabling the DNA replication fork elongation response. Oncotarget. 2016; 7:9732-41. https:// doi.org/10.18632/oncotarget.6947.

84. Nowsheen S, Bonner JA, Yang ES. The poly(ADP-Ribose) polymerase inhibitor ABT- 888 reduces radiation-induced nuclear EGFR and augments head and neck tumor response to radiotherapy. Radiother Oncol. 2011; 99:331-8. https:// doi.org/10.1016/j.radonc.2011.05.084.

85. Dittmann K, Mayer C, Fehrenbacher B, Schaller M, Raju U, Milas L, Chen DJ, Kehlbach R, Rodemann HP. Radiationinduced epidermal growth factor receptor nuclear import is linked to activation of DNA-dependent protein kinase. J Biol Chem. 2005; 280:31182-9. https://doi.org/10.1074/jbc. M506591200.

86. Raben D, Bowles D, Waxweiler T, Karam S, Jimeno A. SP0298: Phase I Results of PARPi (Olaparib) + RT + Cetuximab in LAHNSCC. Radiother Oncol. 2016; 119:S138-9. https:// doi.org/10.1016/S0167-8140(16)31547-X.

87. Khan K, Araki K, Wang D, Li G, Li X, Zhang J, Xu W, Hoover RK, Lauter S, O’Malley B, Lapidus RG, Li D. Head and neck cancer radiosensitization by the novel poly(ADPribose) polymerase inhibitor GPI-15427. Head Neck. 2010; 32:381-91. https://doi.org/10.1002/hed.21195.

88. Verhagen CVM, de Haan R, Hageman F, Oostendorp TPD, Carli ALE, O'Connor MJ, Jonkers J, Verheij M, van den Brekel MW, Vens C. Extent of radiosensitization by the PARP inhibitor olaparib depends on its dose, the radiation dose and the integrity of the homologous recombination pathway of tumor cells. Radiother Oncol. 2015; 116:358 65. https://doi.org/10.1016/j.radonc.2015.03.028.

89. Chow JPH, Man WY, Mao M, Chen H, Cheung F, Nicholls J, Tsao SW, Li Lung M, Poon RYC. PARP1 is overexpressed in nasopharyngeal carcinoma and its inhibition enhances radiotherapy. Mol Cancer Ther. 2013; 12:2517-28. https:// doi.org/10.1158/1535-7163.MCT-13-0010.
90. Zhou ZR, Zhu XD, Zhao W, Qu S, Su F, Huang ST, Ma JL, Li XY. Poly(ADP-ribose) polymerase-1 regulates the mechanism of irradiation-induced CNE-2 human nasopharyngeal carcinoma cell autophagy and inhibition of autophagy contributes to the radiation sensitization of CNE-2 cells. Oncol Rep. 2013; 29:2498-506. https://doi. org/10.3892/or.2013.2382.

91. Mateo J, Carreira S, Sandhu S, Miranda S, Mossop H, Perez-Lopez R, Nava Rodrigues D, Robinson D, Omlin A, Tunariu N, Boysen G, Porta N, Flohr P, et al. DNA-Repair Defects and Olaparib in Metastatic Prostate Cancer. N Engl J Med. 2015; 373:1697-708. https://doi.org/10.1056/ NEJMoa1506859.

92. Rubin MA, Maher CA, Chinnaiyan AM. Common gene rearrangements in prostate cancer. J Clin Oncol. 2011; 29:3659-68. https://doi.org/10.1200/JCO.2011.35.1916.

93. Chatterjee P, Choudhary GS, Alswillah T, Xiong X, Heston WD, Magi-Galluzzi C, Zhang J, Klein EA, Almasan A. The TMPRSS2-ERG Gene Fusion Blocks XRCC4-Mediated Nonhomologous End-Joining Repair and Radiosensitizes Prostate Cancer Cells to PARP Inhibition. Mol Cancer Ther. 2015; 14:1896-906. https:// doi.org/10.1158/1535-7163.MCT-14-0865.

94. Gani C, Coackley C, Kumareswaran R, Schütze C, Krause M, Zafarana G, Bristow RG. In vivo studies of the PARP inhibitor, AZD-2281, in combination with fractionated radiotherapy: An exploration of the therapeutic ratio. Radiother Oncol. 2015; 116:486-94. https://doi. org/10.1016/j.radonc.2015.08.003.

95. Schlicker A, Peschke P, Bürkle A, Hahn EW, Kim JH. 4-Amino-1,8-naphthalimide: a novel inhibitor of poly(ADPribose) polymerase and radiation sensitizer. Int J Radiat Biol. 1999; 75:91-100.

96. Liu SK, Coackley C, Krause M, Jalali F, Chan N, Bristow RG. A novel poly(ADP-ribose) polymerase inhibitor, ABT888 , radiosensitizes malignant human cell lines under hypoxia. Radiother Oncol. 2008; 88:258-68. https://doi. org/10.1016/j.radonc.2008.04.005.

97. Barreto-Andrade JC, Efimova EV, Mauceri HJ, Beckett MA, Sutton HG, Darga TE, Vokes EE, Posner MC, Kron SJ, Weichselbaum RR. Response of human prostate cancer cells and tumors to combining PARP inhibition with ionizing radiation. Mol Cancer Ther. 2011; 10:1185-93. https://doi. org/10.1158/1535-7163.MCT-11-0061.

98. Chatterjee P, Choudhary GS, Sharma A, Singh K, Heston WD, Ciezki J, Klein EA, Almasan A. PARP Inhibition Sensitizes to Low Dose-Rate Radiation TMPRSS2-ERG Fusion Gene-Expressing and PTEN-Deficient Prostate Cancer Cells. PLoS One. 2013; 8:e60408. https://doi. org/10.1371/journal.pone.0060408.

99. Han S, Brenner JC, Sabolch A, Jackson W, Speers C, Wilder-Romans K, Knudsen KE, Lawrence TS, Chinnaiyan AM, Feng FY. Targeted radiosensitization of ETS fusionpositive prostate cancer through PARP1 inhibition. Neoplasia. 2013; 15:1207-17. 
100. Bridges KA, Toniatti C, Buser CA, Liu H, Buchholz TA, Meyn RE. Niraparib (MK-4827), a novel poly(ADPRibose) polymerase inhibitor, radiosensitizes human lung and breast cancer cells. Oncotarget. 2014; 5:5076-86. https://doi.org/10.18632/oncotarget.2083.

101. Kötter A, Cornils K, Borgmann K, Dahm-Daphi J, Petersen C, Dikomey E, Mansour WY. Inhibition of PARP1dependent end-joining contributes to Olaparib-mediated radiosensitization in tumor cells. Mol Oncol. 2014; 8:161625. https://doi.org/10.1016/j.molonc.2014.06.008.

102. Rae C, Mairs RJ. Evaluation of the radiosensitizing potency of chemotherapeutic agents in prostate cancer cells. Int J Radiat Biol. 2017; 93:194-203. https://doi.org/10.1080/09 553002.2017 .1231946$.

103. Jiang Y, Verbiest T, Devery AM, Bokobza SM, Weber AM, Leszczynska KB, Hammond EM, Ryan AJ. Hypoxia Potentiates the Radiation-Sensitizing Effect of Olaparib in Human Non-Small Cell Lung Cancer Xenografts by Contextual Synthetic Lethality. Int J Radiat Oncol Biol Phys. 2016; 95:772-81. https://doi.org/10.1016/j. ijrobp.2016.01.035.

104. Cardnell RJ, Feng Y, Diao L, Fan YH, Masrorpour F, Wang J, Shen Y, Mills GB, Minna JD, Heymach JV, Byers LA. Proteomic markers of DNA repair and PI3K pathway activation predict response to the PARP inhibitor BMN 673 in small cell lung cancer. Clin Cancer Res. 2013; 19:6322-8. https://doi.org/10.1158/1078-0432.CCR-13-1975.

105. Owonikoko TK, Zhang G, Deng X, Rossi MR, Switchenko JM, Doho GH, Chen Z, Kim S, Strychor S, Christner SM, Beumer J, Li C, Yue P, et al. Poly (ADP) ribose polymerase enzyme inhibitor, veliparib, potentiates chemotherapy and radiation in vitro and in vivo in small cell lung cancer. Cancer Med. 2014; 3:1579-94. https://doi.org/10.1002/ cam4.317.

106. Albert JM, Cao C, Kim KW, Willey CD, Geng L, Xiao D, Wang H, Sandler A, Johnson DH, Colevas AD, Low J, Rothenberg ML, Lu B. Inhibition of poly(ADP-ribose) polymerase enhances cell death and improves tumor growth delay in irradiated lung cancer models. Clin Cancer Res. 2007; 13:3033-42. https://doi.org/10.1158/1078-0432.CCR06-2872.

107. Thraves PJ, Mossman KL, Frazier DT, Dritschilo A. Inhibition of potentially lethal radiation damage repair in normal and neoplastic human cells by 3 -aminobenzamide: an inhibitor of poly(ADP-ribosylation). Int J Radiat Oncol Biol Phys. 1986; 12:1541-5.

108. Senra JM, Telfer BA, Cherry KE, McCrudden CM, Hirst DG, O'Connor MJ, Wedge SR, Stratford IJ. Inhibition of PARP-1 by olaparib (AZD2281) increases the radiosensitivity of a lung tumor xenograft. Mol Cancer Ther. 2011; 10:1949-58. https://doi.org/10.1158/15357163.MCT-11-0278.

109. Wang L, Mason KA, Ang KK, Buchholz T, Valdecanas D, Mathur A, Buser-Doepner C, Toniatti C, Milas L. MK4827, a PARP-1/-2 inhibitor, strongly enhances response of human lung and breast cancer xenografts to radiation. Invest New Drugs. 2012; 30:2113-20. https://doi.org/10.1007/ s10637-011-9770-x.

110. Feng FY, Speers C, Liu M, Jackson WC, Moon D, Rinkinen J, Wilder-Romans K, Jagsi R, Pierce LJ. Targeted radiosensitization with PARP1 inhibition: optimization of therapy and identification of biomarkers of response in breast cancer. Breast Cancer Res Treat. 2014; 147:81-94. https://doi.org/10.1007/s10549-014-3085-5.

111. Efimova EV, Mauceri HJ, Golden DW, Labay E, Bindokas VP, Darga TE, Chakraborty C, Barreto-Andrade JC, Crawley C, Sutton HG, Kron SJ, Weichselbaum RR. Poly(ADP-ribose) polymerase inhibitor induces accelerated senescence in irradiated breast cancer cells and tumors. Cancer Res. 2010; 70:6277-82. https://doi. org/10.1158/0008-5472.CAN-09-4224.

112. Jagsi R, Griffith KA, Bellon JR, Woodward WA, Horton JK, Ho AY, Schott A, Pierce LJ. TBCRC 024 Initial Results: A Multicenter Phase 1 Study of Veliparib Administered Concurrently With Chest Wall and Nodal Radiation Therapy in Patients With Inflammatory or Locoregionally Recurrent Breast Cancer. Int J Radiat Oncol Biol Phys. 2015; 93:S137. https://doi.org/10.1016/j.ijrobp.2015.07.326.

113. Kelland LR, Tonkin KS. The effect of 3-aminobenzamide in the radiation response of three human cervix carcinoma xenografts. Radiother Oncol. 1989; 15:363-9.

114. Lee HJ, Yoon C, Schmidt B, Park DJ, Zhang AY, Erkizan HV, Toretsky JA, Kirsch DG, Yoon SS. Combining PARP-1 inhibition and radiation in Ewing sarcoma results in lethal DNA damage. Mol Cancer Ther. 2013; 12:2591-600. https://doi.org/10.1158/1535-7163.MCT-13-0338.

115. IJPT.16-PTCOG-1.pdf. [cited 2017 May 13]. Available from http://www.theijpt.org/doi/pdf/10.14338/IJPT.16PTCOG-1.1

116. Hamdi DH, Barbieri S, Chevalier F, Groetz J-E, Legendre F, Demoor M, Galera P, Lefaix JL, Saintigny Y. In vitro engineering of human 3D chondrosarcoma: a preclinical model relevant for investigations of radiation quality impact. BMC Cancer. 2015; 15:579. https://doi.org/10.1186/s12885015-1590-5.

117. Nonnekens J, van Kranenburg M, Beerens CEMT, Suker M, Doukas M, van Eijck CHJ, de Jong M, van Gent DC. Potentiation of Peptide Receptor Radionuclide Therapy by the PARP Inhibitor Olaparib. Theranostics. 2016; 6:1821-32. https://doi.org/10.7150/thno.15311.

118. McLachlan J, Banerjee S. Olaparib for the treatment of epithelial ovarian cancer. Expert Opin Pharmacother. 2016; 17:995-1003. https://doi.org/10.1517/14656566.2016.1165205.

119. Rodriguez-Lafrasse C, Balosso J. [From the carbon track to therapeutic efficiency of hadrontherapy]. [Article in French]. Cancer Radiother. 2012; 16:16-24. https://doi. org/10.1016/j.canrad.2011.06.006.

120. Lester A, Rapkins R, Nixdorf S, Khasraw M, McDonald K. Combining PARP inhibitors with radiation therapy for the treatment of glioblastoma: Is PTEN predictive of response? 
Clin Transl Oncol. 2017; 19:273-8. https://doi.org/10.1007/ s12094-016-1547-4.

121. LoRusso PM, Li J, Burger A, Heilbrun LK, Sausville EA, Boerner SA, Smith D, Pilat MJ, Zhang J, Tolaney SM, Cleary JM, Chen AP, Rubinstein L, et al. Phase I Safety, Pharmacokinetic, and Pharmacodynamic Study of the Poly(ADP-ribose) Polymerase (PARP) Inhibitor Veliparib (ABT-888) in Combination with Irinotecan in Patients with
Advanced Solid Tumors. Clin Cancer Res. 2016; 22:3227-37. https://doi.org/10.1158/1078-0432.CCR-15-0652.

122. Stover EH, Konstantinopoulos PA, Matulonis UA, Swisher EM. Biomarkers of Response and Resistance to DNA Repair Targeted Therapies. Clin Cancer Res Off J Am Assoc Cancer Res. 2016; 22:5651-60. https://doi. org/10.1158/1078-0432.CCR-16-0247. 